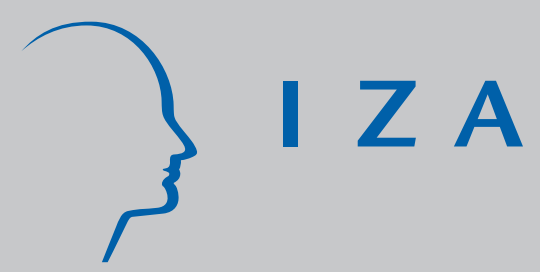

IZA DP No. 514

The Size and Development of the Shadow Economies of 22 Transition and 21 OECD Countries

Friedrich Schneider

J une 2002 


\title{
The Size and Development of the Shadow Economies of 22 Transition and 21 OECD Countries
}

\author{
Friedrich Schneider \\ University of Linz and IZA Bonn
}

Discussion Paper No. 514

June 2002

IZA

P.O. Box 7240

D-53072 Bonn

Germany

Tel.: +49-228-3894-0

Fax: +49-228-3894-210

Email: iza@iza.org

This Discussion Paper is issued within the framework of IZA's research area Labor Markets in Transition Countries. Any opinions expressed here are those of the author(s) and not those of the institute. Research disseminated by IZA may include views on policy, but the institute itself takes no institutional policy positions.

The Institute for the Study of Labor (IZA) in Bonn is a local and virtual international research center and a place of communication between science, politics and business. IZA is an independent, nonprofit limited liability company (Gesellschaft mit beschränkter Haftung) supported by the Deutsche Post AG. The center is associated with the University of Bonn and offers a stimulating research environment through its research networks, research support, and visitors and doctoral programs. IZA engages in (i) original and internationally competitive research in all fields of labor economics, (ii) development of policy concepts, and (iii) dissemination of research results and concepts to the interested public. The current research program deals with (1) mobility and flexibility of labor, (2) internationalization of labor markets, (3) the welfare state and labor markets, (4) labor markets in transition countries, (5) the future of labor, (6) evaluation of labor market policies and projects and (7) general labor economics.

IZA Discussion Papers often represent preliminary work and are circulated to encourage discussion. Citation of such a paper should account for its provisional character. A revised version may be available on the IZA website (www.iza.org) or directly from the author. 
IZA Discussion Paper No. 514

June 2002

\section{ABSTRACT \\ The Size and Development of the Shadow Economies of 22 Transition and 21 OECD Countries*}

Using the currency demand and DYMIMIC approaches estimates are presented about the size of the shadow economy in 22 Transition and 21 OECD countries. Over 2001/2002 in 21 OECD countries is the average size of the shadow economy (in percent of official GDP) $16.7 \%$ of "official" GDP and of 22 Transition countries $38.0 \%$. The average size of the shadow economy labor force (in percent of the population of working age) of the year $1998 / 99$ in 7 OECD-countries is $15.3 \%$ and in 22 Transition countries is $30.2 \%$. An increasing burden of taxation and social security contributions combined with rising state regulatory activities are the driving forces for the growth and size of the shadow economy (labor force).

JEL Classification: O17, O5, D78, H2, H26

Keywords: shadow economy, transition economies, tax and social security burden, government regulation

Friedrich Schneider

Department of Economics

Johannes Kepler University of Linz

Altenbergerstrasse 69

A-4040 Linz-Auhof

Austria

Tel.: +43-70-2468-8210

Fax: +43-70-2468-8209

email: friedrich.schneider@jku.at

"Invited paper prepared for the Round Table Conference: "On the Informal Economy", Sofia, Bulgaria, April 18-20, 2002. 


\section{Contents}

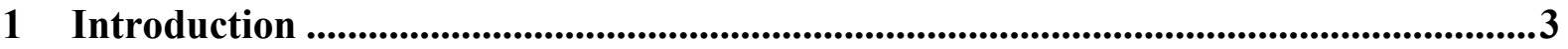

2 The Definition of a Shadow Economy: An Attempt ....................................................4

3 The Size of the Shadow Economies (Labor Force) in 22 Transition and 21 OECD

Countries.

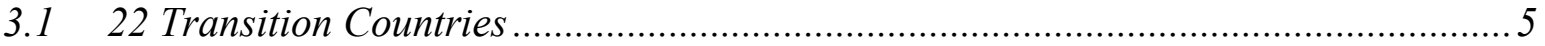

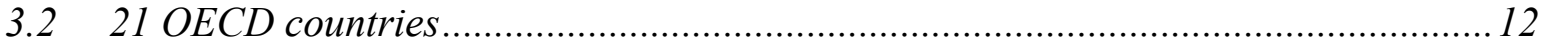

$3.3 \quad$ Further results for the German-speaking Countries ...............................................20

4 The Main Causes of the Increase of the Shadow Economy .......................................25

4.1 Increase of the Tax and Social Security Contribution Burdens ..................................22

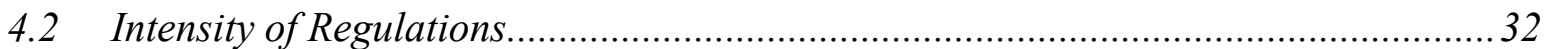

5 Some Methods to Estimate the Size of the Shadow Economy .....................................33

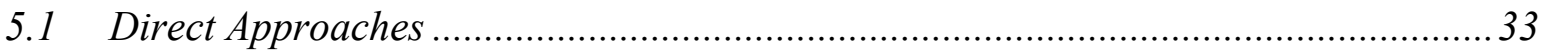

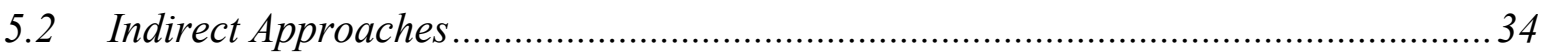

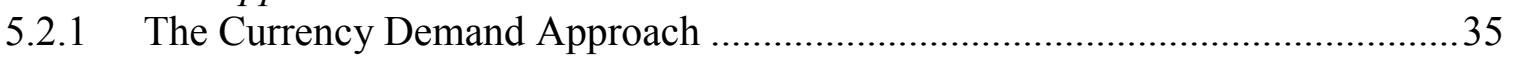

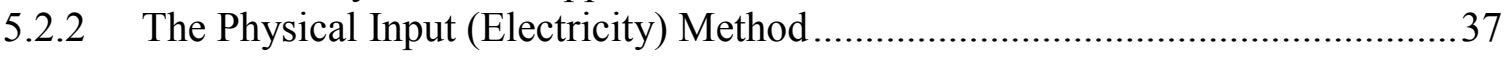

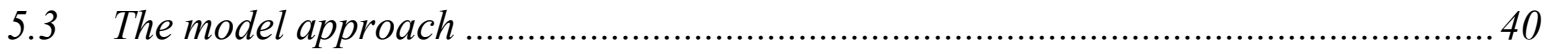

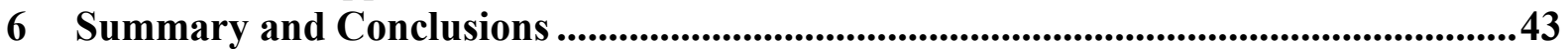

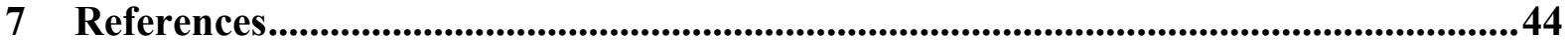




\section{Introduction}

As crime and other underground economic activities (including shadow economic ones) are a fact of life around the world, most societies attempt to control these activities through various measures like punishment, prosecution, economic growth or education. Gathering statistics about who is engaged in underground (or crime) activities, the frequencies with which these activities are occurring and the magnitude of them, is crucial for making effective and efficient decisions regarding the allocations of a country's resources in this area. Unfortunately, it is very difficult to get accurate information about these underground (or as a subset shadow economy) activities in terms of value added and of labor market, because all individuals engaged in these activities wish not to be identified.

Although quite a large literature ${ }^{1)}$ on single aspects of the hidden (shadow) economy exists and a comprehensive survey has just been written by Schneider (the author of this paper) and Enste concentrating on the size of the shadow economy in terms of value added, the subject is still quite controversial ${ }^{2)}$ and there are disagreements about the definition of shadow economy activities, the estimation procedures and the use of their estimates in economic analysis and policy aspects. ${ }^{3)}$ In spite of these difficulties in Transition and OECD countries there are strong indications for an increase of the shadow economy since the late 80 s but little is known of the size and development of the shadow economies in Transition and OECD countries over the 90 s (up to the year 2000 !).

The scientific fascination of the underground economy has inspired me to tackle this difficult question and undertake the challenging task to estimate the shadow economy in Transition and OECD-countries over the 90s. In section 2 an attempt is made to define the shadow economy. Section 3 presents the empirical results of the size of the shadow economy over 22 Transition and over 21 OECD countries as well as first and preliminary empirical results of the size of the shadow economy labor force (informal employment) in some of these countries over the 90 s. Section 4 examines the main causes of the shadow economy. In

\footnotetext{
1) The literature about the „shadow“, „,underground“, „informal“, „,second“", “cash-“" or „parallel“, economy is increasing. Various topics, on how to measure it, its causes, its effect on the official economy are analyzed. See for example, survey type publications by Frey and Pommerehne (1984); Thomas (1992); Loayza (1996); Pozo (1996); Lippert and Walker (1997); Schneider (1994a, 1994b, 1997, 1998a); Johnson, Kaufmann, and Shleifer (1997), and Johnson, Kaufmann and Zoido-Lobatón (1998a); and for an overall survey of the global evidence of its size in terms of value added compare Schneider and Enste (2000).

2) Compare e.g. in the Economic Journal, vol. 109, no. 456, June 1999 the feature "controversy: on the hidden economy".

${ }^{3)}$ Compare the different opinions of Tanzi (1999), Thomas (1999) and Giles (1999a,b).
} 
section 5 some methods to estimate the size of the shadow economy are shortly presented, and in section 6 a summary is given and some conclusions are drawn.

\section{The Definition of a Shadow Economy: An Attempt}

Most authors trying to measure the shadow economy face the difficulty of how to define it. One commonly used working definition is: all currently unregistered economic activities which contribute to the officially calculated (or observed) Gross National Product. ${ }^{4)}$ Smith (1985, p. 18) defines it as ,market-based production of goods and services, whether legal or illegal that escapes detection in the official estimates of GDP." As these definitions still leave open a lot of questions, table 1 may be helpful for developing a better feeling for what could be a reasonable consensus definition of the legal and illegal underground or shadow economy.

From table 1 it becomes clear that the shadow economy includes unreported income from the production of legal goods and services either from monetary or barter transactions - hence all economic activities which would generally be taxable were they reported to the state (tax) authorities. In general, a precise definition seems quite difficult, if not impossible as ,the shadow economy develops all the time according to the 'principle of running water': it adjusts to changes in taxes, to sanctions from the tax authorities and to general moral attitudes, etc." (Mogensen, et. al. 1995 p. 5).

Table 1: A Taxonomy of Types of Underground Economic Activities ${ }^{1)}$

\begin{tabular}{|c|c|c|c|c|}
\hline Type of Activity & \multicolumn{2}{|c|}{ Monetary Transactions } & \multicolumn{2}{|c|}{ Non Monetary Transactions } \\
\hline \multirow[t]{2}{*}{$\begin{array}{l}\text { Illegal } \\
\text { Activities }\end{array}$} & \multicolumn{2}{|c|}{$\begin{array}{l}\text { Trade with stolen goods; drug dealing } \\
\text { and manufacturing; prostitution; } \\
\text { gambling; smuggling and fraud }\end{array}$} & \multicolumn{2}{|c|}{$\begin{array}{l}\text { Barter of drugs, stolen goods, } \\
\text { smuggling etc. Produce or growing } \\
\text { drugs for own use. Theft for own } \\
\text { use. }\end{array}$} \\
\hline & Tax Evasion & $\begin{array}{l}\text { Tax } \\
\text { Avoidance }\end{array}$ & Tax Evasion & Tax Avoidance \\
\hline $\begin{array}{l}\text { Legal } \\
\text { Activities }\end{array}$ & $\begin{array}{l}\text { Unreported income } \\
\text { from self- } \\
\text { employment; Wages, } \\
\text { salaries and assets } \\
\text { from unreported work } \\
\text { related to legal } \\
\text { services and goods }\end{array}$ & $\begin{array}{l}\text { Employee } \\
\text { discounts, } \\
\text { fringe benefits }\end{array}$ & $\begin{array}{l}\text { Barter of legal } \\
\text { services and } \\
\text { goods }\end{array}$ & $\begin{array}{l}\text { All do-it-yourself } \\
\text { work and } \\
\text { neighbor help }\end{array}$ \\
\hline
\end{tabular}

${ }^{1)}$ Structure of the table is taken from Lippert and Walker (1997, p. 5) with additional remarks.

\footnotetext{
4) This definition is used for example, by Feige $(1989,1994)$, Schneider (1994a), Frey and Pommerehne (1984), and Lubell (1991).
} 


\section{The Size of the Shadow Economies (Labor Force) in 22 Transition and 21 OECD Countries}

\subsection{Transition Countries}

The physical input (electricity) method and DYMIMIC method have been applied to the transition countries in Central and Eastern Europe and to states of the former Soviet Union. The results are shown in table 2 and in figure 2.1 to 2.4; they cover the periods 1990-93, 1994-95 and 2000/2001. Considering the physical input method by Johnson et. al and the countries of the former Soviet Union over the period 1990-93, Georgia has the largest shadow economy with 43.6 percent of "official" GDP, followed by Azerbaijan with 33.8 percent and Moldova 29.1 percent. Russia can be found in middle with a shadow economy of 27 percent. According to the Johnson et. al. Figures Belarus with 14 percent and Uzbekistan with 10.3 percent have the smallest values. Except Uzbekistan all other former Soviet Union countries experienced a strong increase in the shadow economy from an average of 25.7 percent for 1990-93 to 35.3 percent for 1994-95, calculated over all 12 countries of the former Soviet Union. Turning to the transition countries of Central and Eastern Europe and considering the period 1990-93 and the Johnson et. al. figures Hungary has the largest shadow economy with 30.7 percent of GDP followed by Bulgaria with 26.3 percent. The lowest two are the Czech Republic with 13.4\% and Slovakia with 14.2\%. The Johnson et. al figures show an average shadow economy of the Central and Eastern European states of $22.4 \%$ over 1990-93 and over the period 1994-95 Johnson et. al. shows an average size of the shadow economy of the Central and Eastern European states of 25.1\%. Turning to the size of the shadow economy, estimated by the DYMIMIC method for the 13 former Soviet Union countries the average size is $32.9 \%$ and for the 9 Central and Eastern European countries the average size is 23.4 for the year 1990/93. Both values are in similar range compared with the ones of the physical input method and most single country estimates come quite close to the one estimated by Johnson et.al. (1997). Considering the years 2000/2001, Georgia has the largest shadow economy with $66.1 \%$ of official GDP, followed by Azerbaijan with $60.1 \%$ of "official" GDP and Ukraine with 51.2\% of official GDP. The lowest shadow economy on the Former Soviet Union countries has Uzbekistan with 33.4\% of official GDP and Kyrgyzstan with $39.4 \%$ of official GDP and Latvia with $39.6 \%$ of official GDP. On average the shadow economy has reached the value of $44.8 \%$ of official GDP for the years $2000 / 2001$ which is a considerable increase compared to the average of the years 1990/1993. If we turn now to the Central and Eastern Europe, we see that in the years 2000/2001 again using the DYMIMIC 
method Macedonia has with 45.1\% of official GDP the largest shadow economy followed by Bulgaria with $36.4 \%$ of official GDP and Romania with $33.4 \%$ of official GDP. The smallest has Slovakia with $18.3 \%$ of official GDP and the Czech Republic with $18.4 \%$ of official GDP. The average size of the shadow economy in the 9 Central and Eastern European Transition Countries has increased from 23.4\% (of official GDP) of the years 1990/93 to $29.2 \%$ (of official GDP) of the years 2000/2001. If we finally discuss the size of the shadow economy labor force in percent of the population, we see of the Former Soviet Union Transition Countries, Georgia has with 53.2\% the biggest shadow economy labor force, followed by Azerbaijan with 50.7\% and Ukraine with 41.2\%. The lowest has Lithuania with 20.3\% and Kyrgyzstan with 29.4\%. Turning to the Central and Eastern Europe, considering here the shadow economy labor force, we see that the Czech Republic has with $12.6 \%$ the lowest, followed by Slovakia with $16.3 \%$ and the largest has Macedonia with $35.1 \%$, followed by Bulgaria with $30.4 \%$ and Croatia with $27.4 \%$. In general, the size of the shadow economy and also the size of the shadow economy labor force is quite remarkable for this 22 Transition countries and has strangely risen up to the year 2000/2001. 


\begin{tabular}{|c|c|c|c|c|c|}
\hline \multicolumn{6}{|c|}{ Table 2: The Size of the Shadow Economy in Transition Countries } \\
\hline \multirow{3}{*}{ Transition Countries } & \multicolumn{4}{|c|}{ Size of the Shadow Economy (in \% of GDP) } & \multirow{3}{*}{\begin{tabular}{|c|} 
Shadow \\
Economy Labor \\
Force in \% of \\
(Working Age) \\
Population \\
$1998 / 99$
\end{tabular}} \\
\hline & \multicolumn{2}{|c|}{$\begin{array}{l}\text { Physical Input (Electricity) } \\
\text { Method Using Values from } \\
\text { Johnson et. al. (1997) }\end{array}$} & \multicolumn{2}{|c|}{ DYMIMIC Method } & \\
\hline & \begin{tabular}{|c|} 
Average \\
$1990-93$
\end{tabular} & $\begin{array}{l}\text { Average } \\
1994-95\end{array}$ & $\begin{array}{c}\text { Average } \\
1990-93\end{array}$ & $\begin{array}{l}\text { Average } \\
2000 / 01\end{array}$ & \\
\hline \multicolumn{6}{|l|}{ Former Soviet Union } \\
\hline 1. Armenia & 39.4 & 40.3 & 40.1 & 45.3 & 40.3 \\
\hline 2. Azerbaijan & 43.8 & 59.3 & 45.1 & 60.1 & 50.7 \\
\hline 3. $\quad$ Belarus & 34.0 & 39.1 & 35.6 & 47.1 & 40.9 \\
\hline 4. $\quad$ Estonia & 33.9 & 38.5 & 34.3 & 39.1 & 33.4 \\
\hline 5. $\quad$ Georgia & 43.6 & 63.0 & 45.1 & 66.1 & 53.2 \\
\hline 6. Kazakhstan & 32.2 & 34.2 & 31.9 & 42.2 & 33.6 \\
\hline 7. Kyrgyzstan & 34.1 & 37.2 & 35.2 & 39.4 & 29.4 \\
\hline 8. Latvia & 24.3 & 34.8 & 25.7 & 39.6 & 29.6 \\
\hline 9. Lithuania & 26.0 & 25.2 & 26.0 & 29.4 & 20.3 \\
\hline 10. Moldavia & 29.1 & 37.7 & 29.3 & 44.1 & 35.1 \\
\hline 11. Russia & 27.0 & 41.0 & 27.8 & 45.1 & 40.9 \\
\hline 12. Ukraine & 38.4 & 47.3 & 29.4 & 51.2 & 41.2 \\
\hline 13. Uzbekistan & 20.3 & 28.0 & 22.1 & 33.4 & 33.2 \\
\hline $\begin{array}{l}\text { Unweighted Average: } \\
\text { former Soviet Union } \\
\text { Countries }\end{array}$ & 32.8 & 40.4 & 32.9 & 44.8 & 37.1 \\
\hline \multicolumn{6}{|c|}{ Central and Eastern Europe } \\
\hline 1. $\quad$ Bulgaria & 26.3 & 32.7 & 27.1 & 36.4 & 30.4 \\
\hline 2. Croatia & 23.5 & 28.5 & 24.6 & 32.4 & 27.4 \\
\hline 3. Czech Republic & 13.4 & 14.5 & 13.1 & 18.4 & 12.6 \\
\hline 4. Hungary & 20.7 & 28.4 & 22.3 & 24.4 & 20.9 \\
\hline 5. Macedonia & 34.5 & 40.3 & 35.6 & 45.1 & 35.1 \\
\hline 6. $\quad$ Poland & 20.3 & 13.9 & 22.3 & 27.4 & 20.9 \\
\hline 7. Romania & 26.0 & 28.3 & 27.3 & 33.4 & 24.3 \\
\hline 8. $\quad$ Slovakia & 14.2 & 15.2 & 15.1 & 18.3 & 16.3 \\
\hline 9. $\quad$ Slovenia & 22.4 & 23.9 & 22.9 & 26.7 & 21.6 \\
\hline $\begin{array}{l}\text { Unweighted Average: } \\
\text { Central and Eastern } \\
\text { European Countries }\end{array}$ & 22.4 & 25.1 & 23.4 & 29.2 & 23.3 \\
\hline
\end{tabular}

1) Working age population means population between the age of 16 and 65 .

Sources: Own calculations using the DYMIMIC method and values using the Physical input method are from Johnson, Kaufmann, and Shleifer (1997, table 1, p. 182-183), Johnson, Kaufmann, and Zoida-Lobatón (1998a, p. 351). 
Figur 2.1: Size of the Shadow Economy (in \% of GDP) in the Former Soviet Union Average 2000/2001

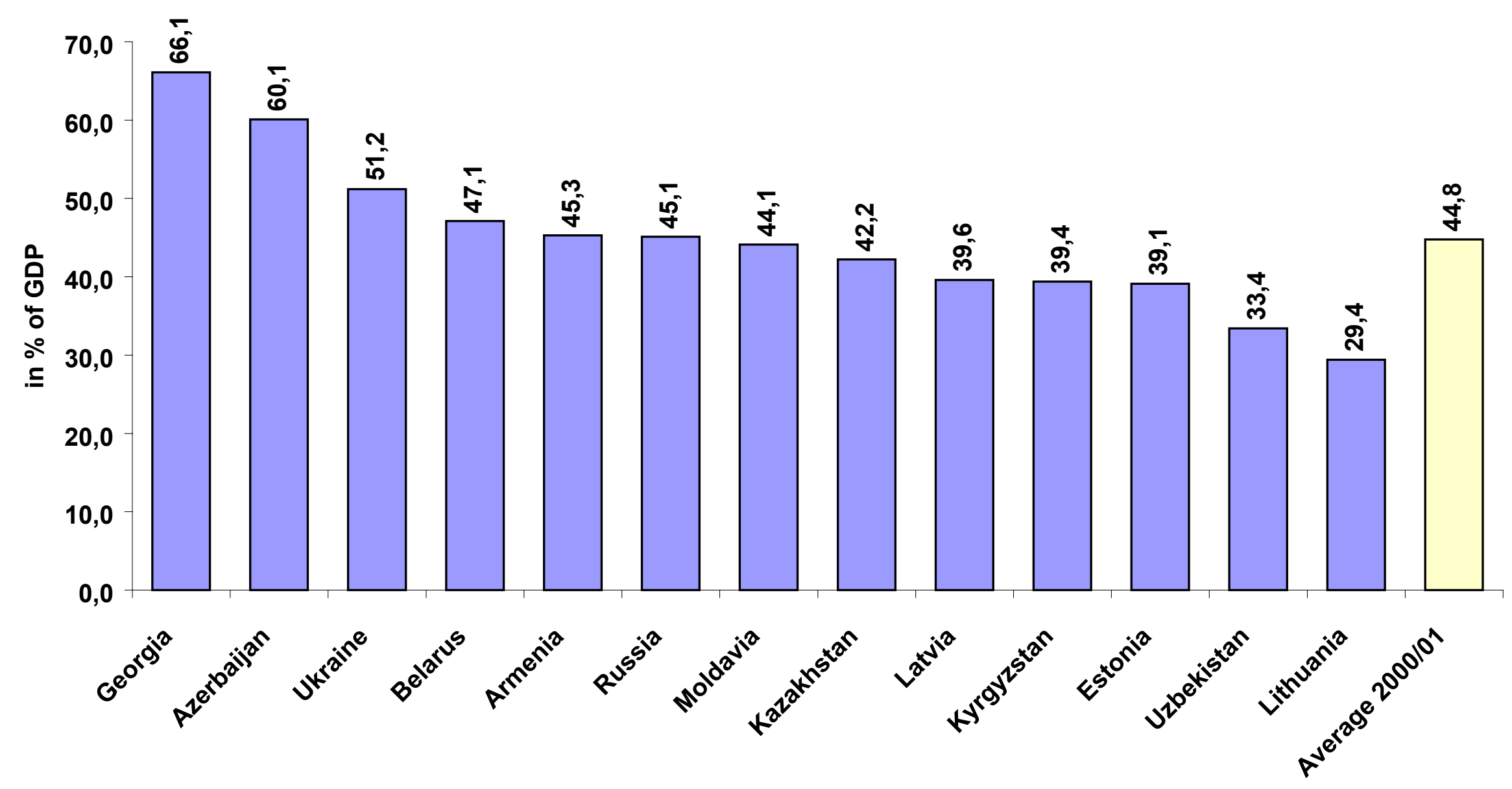


Figur 2.2: Size of the Shadow Economy (in \% of GDP) in Central and Eastern Europe Average 2000/2001

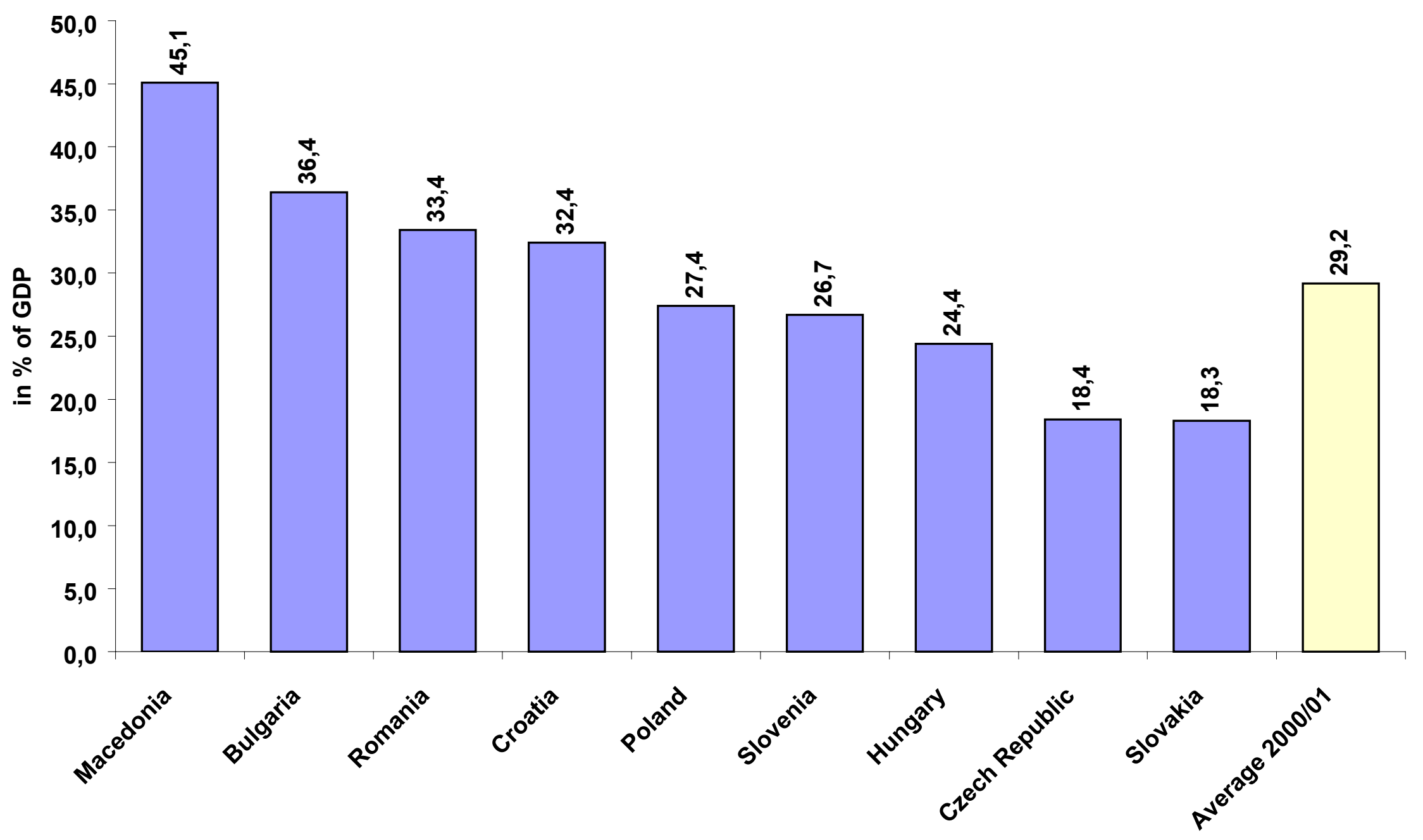


Figur 2.3: Shadow Economy Labor Force in \% of (Working Age) Population in

Transition Countries - Former Soviet Union, 1998/88

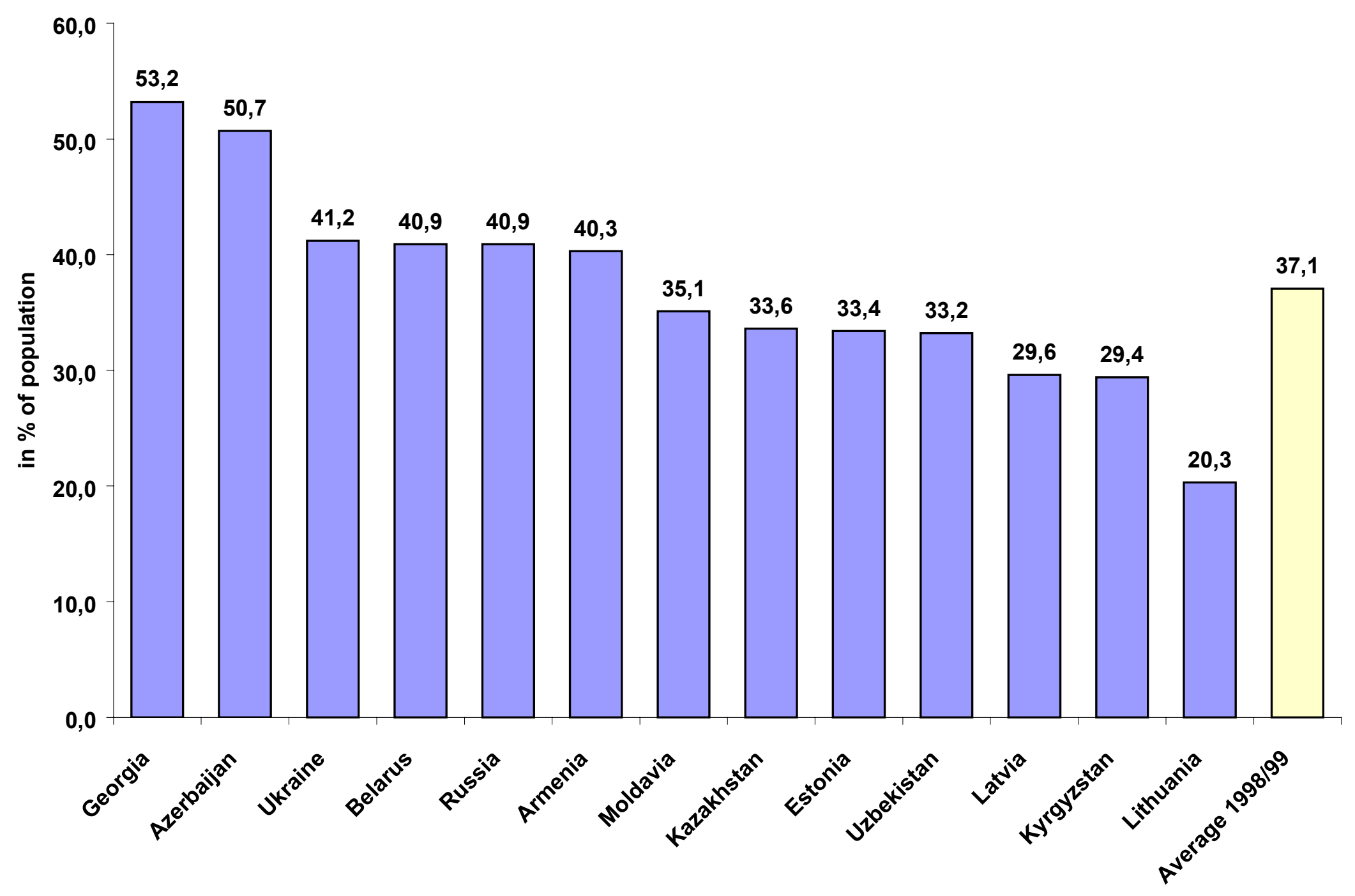


Figur 2.4: Shadow Economy Labor Force in \% of (Working Age) Population in Transition Countries - Central and Eastern Europe, 1998/99

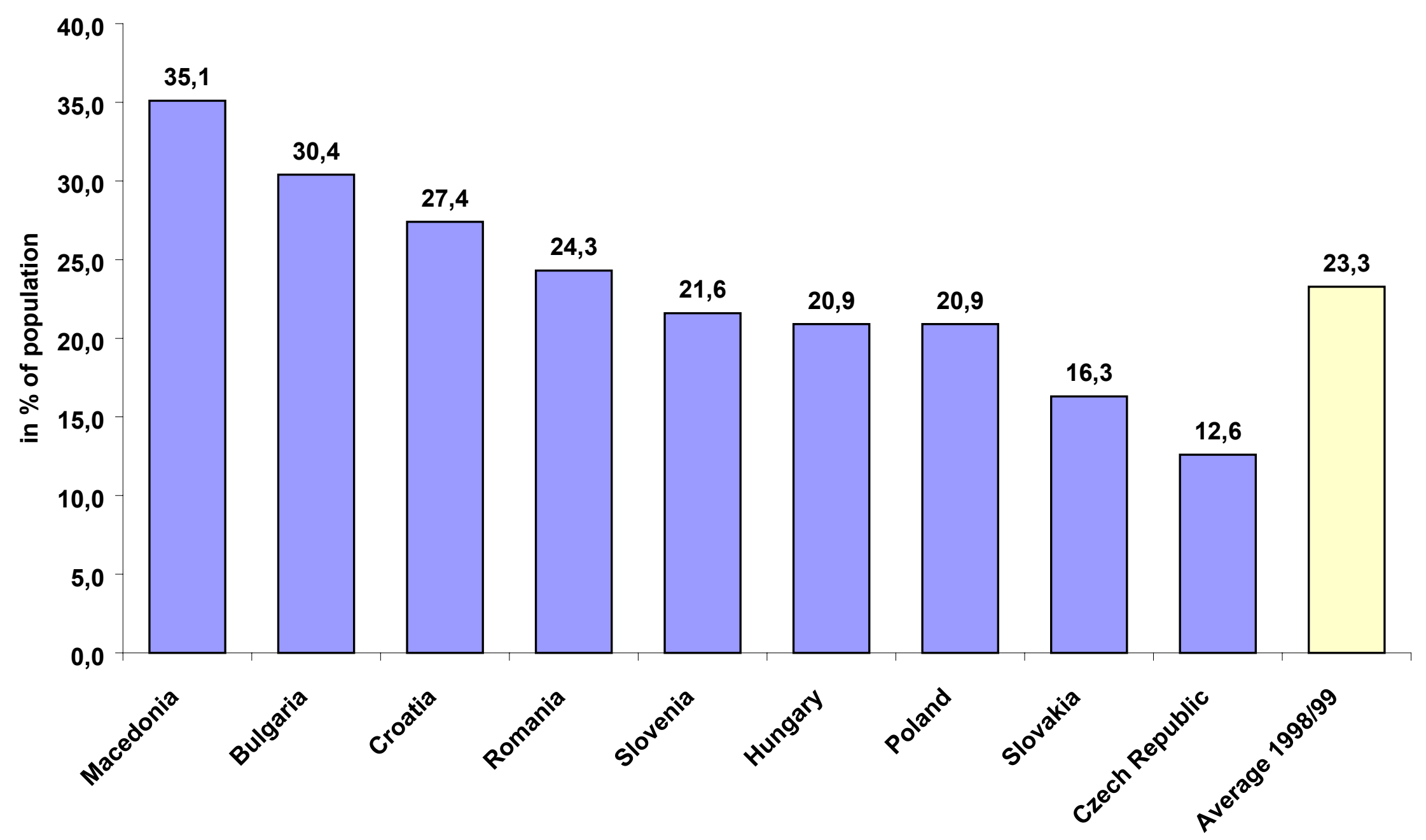




\subsection{OECD countries}

For the 21 OECD countries either the currency demand method or the DYMIMIC method are used to estimate the size of the shadow economy. The results for these countries are shown in table 3 and in figures 3.1 to 3.3 over the period 1989/90 to 2000/2001. Considering again the latest period 2000/2001, Greece has with 28.5\% of "official" GDP the largest shadow economy, followed by Italy with $27.0 \%$ and Portugal with $22.5 \%$. In the middle-field are Germany with a shadow economy of $16.3 \%$ of "official" GDP, followed by Ireland with $15.7 \%$ and France with $15.0 \%$ of official GDP. At the lower end are Austria with $10.6 \%$ of "official" GDP, Switzerland with 9.4\% of "official" GDP and the United States with $8.7 \%$ of "official" GDP. In OECD countries one realizes an increase of the shadow economies during the $90 \mathrm{~s}$. On average the shadow economy was $13.2 \%$ in these 21 OECD states in the year $1989 / 90$ and it rose to $16.7 \%$ in the year $2001 / 2002$. That is an increase by 3.5 percentage points. But we can also see that this increase is considerably smaller compared to the one of 22 Transition countries with 9.9 percentage points of "official" GDP (over the same period). If we consider the second half of the 90s, we realize that for 14 out of the 21 OECD countries the shadow economy is not further increasing, even slightly decreasing, like for Belgium from $22.5 \%$ (1997/98) to $22.0 \%$ (2001/2002), for Denmark from $18.3 \%$ (1997/98) to $17.9 \%$ (2001/2002) or for Finland from 18.9\% (1997/98) to 18.0\% (2001/2002). 6 out of the 21 OECD countries, like New Zealand, it is still increasing from $11.9 \%$ (1997/98) to $12.6 \%$ (2001/2002), or Germany from 14.9\% (1997/98) to 16.3 (2001/2002) or Austria from 9.0\% (1997/98) to $10.6 \%(2001 / 2002)$. Hence, one draw the conclusion that for 14 out of 21 countries the shadow economy is slightly decreasing at the end of the $90 \mathrm{~s}$. The decrease differs from country to country but in some countries some efforts have been made to stabilize (or to decrease) the size of the shadow economy and in other countries (like Germany) these efforts were not successfully. 
Table 3: The Size of the Shadow Economy in OECD Countries

\begin{tabular}{|c|c|c|c|c|c|c|c|}
\hline \multirow[b]{2}{*}{ OECD-Countries } & \multicolumn{7}{|c|}{ Size of the Shadow Economy (in \% of GDP) using the Currency Demand Method } \\
\hline & $\begin{array}{l}\text { Average } \\
1989 / 90\end{array}$ & $\begin{array}{l}\text { Average } \\
1991 / 92\end{array}$ & $\begin{array}{l}\text { Average } \\
1994 / 95\end{array}$ & $\begin{array}{l}\text { Average } \\
1997 / 98\end{array}$ & $\begin{array}{l}\text { Average } \\
1999 / 2000\end{array}$ & $\begin{array}{c}\text { Average } \\
\text { 2001/2002') }\end{array}$ & $\begin{array}{l}\text { Increase }(+) \text { or Decrease of the shad. } \\
\text { econ. }(-) \text { from } 1997 / 98 \text { to } 2001 / 02\end{array}$ \\
\hline 1. Australia & 10.1 & 13.0 & 13.5 & 14.0 & 14.3 & 14.1 & +0.1 \\
\hline 2. Austria & 6.9 & 7.1 & 8.6 & 9.0 & 9.8 & 10.6 & +1.6 \\
\hline 3. Belgium & 19.3 & 20.8 & 21.5 & 22.5 & 22.2 & 22.0 & -0.5 \\
\hline 4. Canada & 12.8 & 13.5 & 14.8 & 16.2 & 16.0 & 15.8 & -0.4 \\
\hline 5. Denmark & 10.8 & 15.0 & 17.8 & 18.3 & 18.0 & 17.9 & -0.4 \\
\hline 6. Finland & 13.4 & 16.1 & 18.2 & 18.9 & 18.1 & 18.0 & -0.9 \\
\hline 7. France & 9.0 & 13.8 & 14.5 & 14.9 & 15.2 & 15.0 & +0.1 \\
\hline 8. Germany & 11.8 & 12.5 & 13.5 & 14.9 & 16.0 & 16.3 & +1.4 \\
\hline 9. Great Britain & 9.6 & 11.2 & 12.5 & 13.0 & 12.7 & 12.5 & -0.5 \\
\hline 10. Greece & 22.6 & 24.9 & 28.6 & 29.0 & 28.7 & 28.5 & -0.5 \\
\hline 11. Ireland & 11.0 & 14.2 & 15.4 & 16.2 & 15.9 & 15.7 & -0.5 \\
\hline 12. Italy & 22.8 & 24.0 & 26.0 & 27.3 & 27.1 & 27.0 & -0.3 \\
\hline 13. Japan & 8.8 & 9.5 & 10.6 & 11.1 & 11.2 & 11.1 & $\mathbf{0 . 0}$ \\
\hline 14. Netherlands & 11.9 & 12.7 & 13.7 & 13.5 & 13.1 & 13.0 & -0.5 \\
\hline 15. New Zealand ${ }^{2)}$ & 9.2 & 9.0 & 11.3 & 11.9 & 12.8 & 12.6 & +0.7 \\
\hline 16. Norway & 14.8 & 16.7 & 18.2 & 19.6 & 19.1 & 19.0 & -0.6 \\
\hline 17. Portugal & 15.9 & 17.2 & 22.1 & 23.1 & 22.7 & 22.5 & -0.6 \\
\hline 18. Spain ${ }^{3)}$ & 16.1 & 17.3 & 22.4 & 23.1 & 22.7 & 22.5 & -0.6 \\
\hline 19. Sweden & 15.8 & 17.0 & 19.5 & 19.9 & 19.2 & 19.1 & -0.8 \\
\hline 20. Switzerland & 6.7 & 6.9 & 7.8 & 8.1 & 8.6 & 9.4 & +1.3 \\
\hline 21. USA & 6.7 & 8.2 & 8.8 & 8.9 & 8.7 & 8.7 & -0.2 \\
\hline Unweighted Average over 21 OECD countries & 13.2 & 14.3 & 15.7 & 16.7 & 16.8 & 16.7 & -0.01 \\
\hline
\end{tabular}

Sources: Currency demand approach, own calculations

1) Preliminary values.

2) The figures are calculated using the MIMIC-method and Currency demand approach. Source: Giles (1999b).

3) The figures have been calculated for 1989/90, 1990/93 and 1994/95 from Mauleon (1998) and for 1997/98, 1999/2000 and 2001/2002 own calculations. 
Figur 3.1: Size of the Shadow Economy in 21 OECD Countries, in \% of GDP, average over 2001/2002

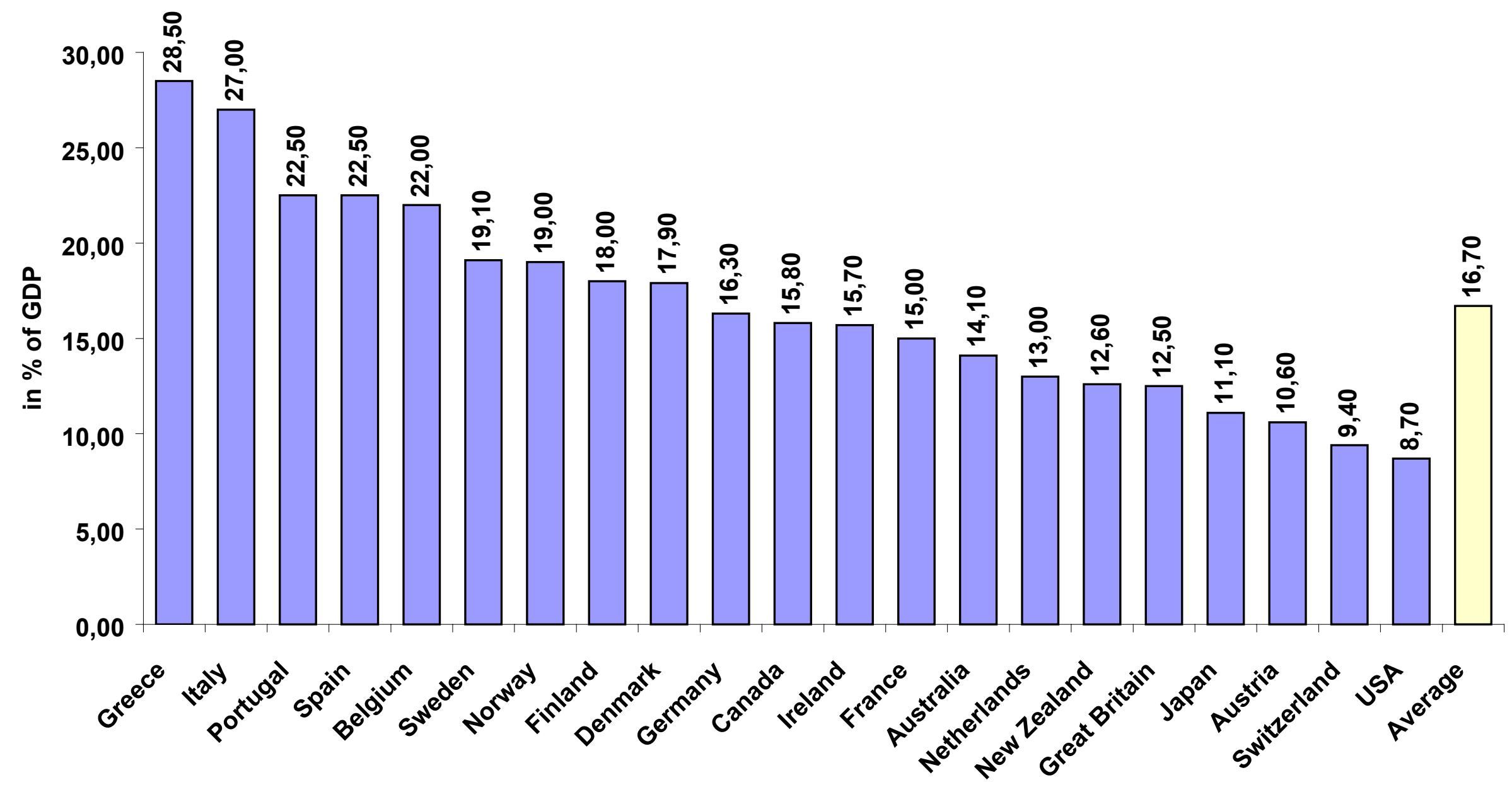


Figur 3.2: Increase of the Size of the Shadow Economy in 21 OECD Countries in \% of GDP over $1989 / 90$ to $2001 / 02$

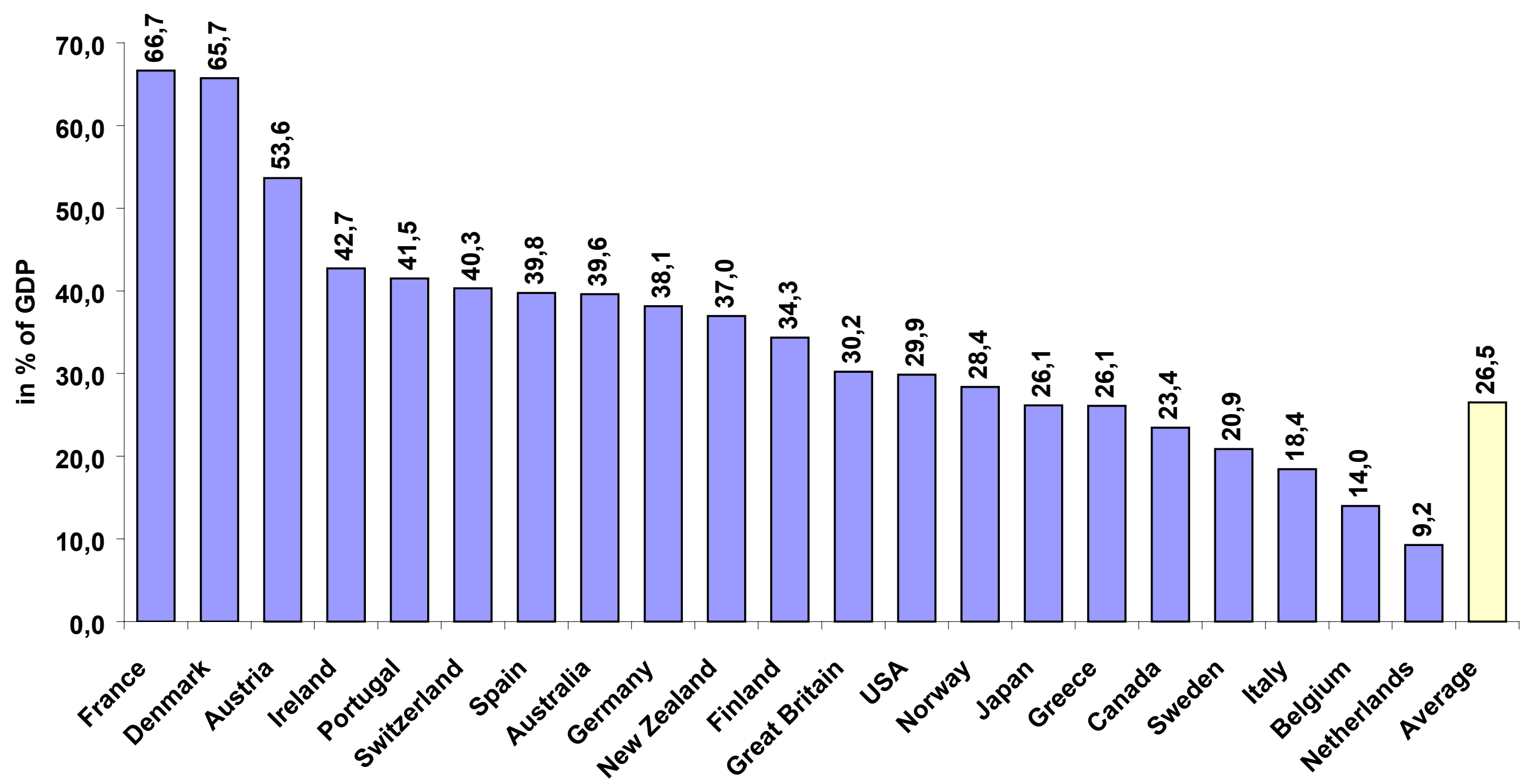


Figure 3.3: Increase (+) or Decrease (-) of the Shadow Economy of 21 OECD Countries from 1997/98 to 2001/2002

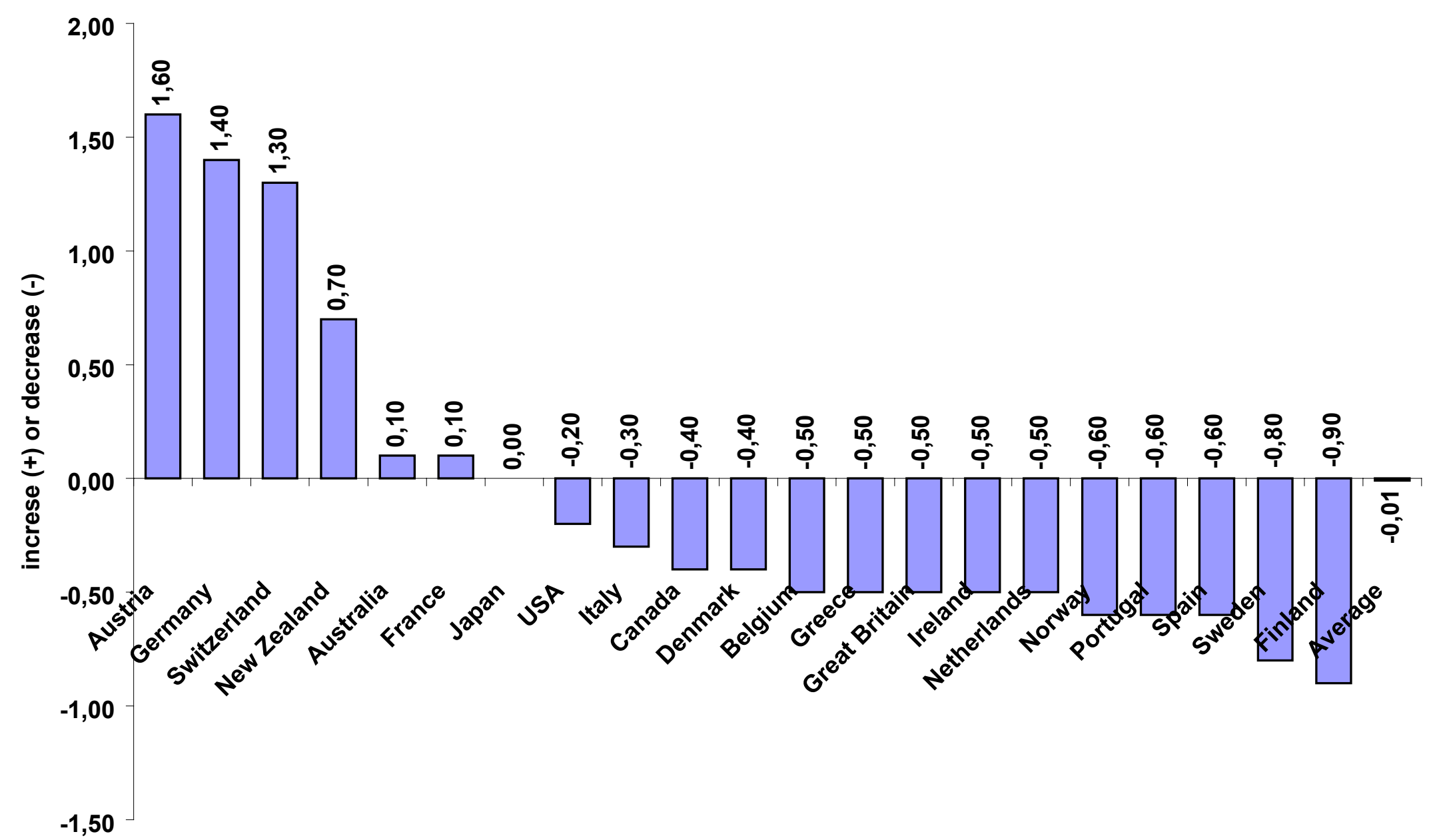


Having examined the size and rise of the shadow economy in terms of value added over time, the analysis now focuses on the „shadow“ labor market, as within the official labor market there is a particularly tight relationship and "social network" between people who are active in the shadow economy. ${ }^{5)}$ Moreover, by definition every activity in the shadow economy involves a "shadow" labor market to some extent: Hence, the "shadow labor market" includes all cases, where the employees or the employers, or both, occupy a „shadow economy position“. Why do people work in the shadow economy? In the official labor market, the costs firms (and individuals) have to pay when "officially" hiring someone are increased tremendously by the burden of tax and social contributions on wages, as well as by the legal administrative regulation to control economic activity. ${ }^{6}$ ) In various OECD countries, these costs are greater than the wage effectively earned by the worker - providing a strong incentive to work in the shadow economy. More detailed theoretical information on the labor supply decision in the underground economy is given by Lemieux, Fortin, and Fréchette (1994) who use micro data from a survey conducted in Quebec City (Canada). In particular, their study provides some economic insight into the size of the distortion caused by income taxation and the welfare system. The results of this study suggest that hours worked in the shadow economy are quite responsive to changes in the net wage in the regular (official) sector. Their empirical results attribute this to a (miss-)allocation of work from the official to the informal sector, where it is not taxed. In this case, the substitution between labor-market activities in the two sectors is quite high. These empirical findings clearly indicate, that "participation rates and hours worked in the underground sector also tend to be inversely related to the number of hours worked in the regular sector" (Lemieux, Fortin, and Fréchette 1994 p. 235). These findings demonstrate a large negative elasticity of hours worked in the shadow economy with respect both to the wage rate in the regular sector as well as to a high mobility between the sectors.

Illicit work can take many shapes. The underground use of labor may consist of a second job after (or even during) regular working hours. A second form is shadow economy work by individuals who do not participate in the official labor market. A third component is the employment of people (e.g. clandestine or illegal immigrants), who are not allowed to work in the official economy. Empirical research on the shadow economy labor market is even more difficult than of the shadow economy on the value added, since one has very little

\footnotetext{
${ }^{5)}$ Pioneering work in this area has been done by L. Frey (1972, 1975, 1978, 1980), Cappiello (1986), Lubell (1991), Pozo (1996), Bartlett (1998) and Tanzi (1999).

${ }^{6)}$ This is especially true in Europe (e.g. in Germany and Austria), where the total tax and social security burden adds up to $100 \%$ on top of the wage effectively earned; see also section 5.1 .
} 
knowledge about how many hours an average "shadow economy worker" is actually working (from full time to a few hours, only); hence, it is not easy to provide empirical facts. ${ }^{7)}$

In table 4 the estimates for the shadow economy labor force in 7 OECD-countries (Austria, Denmark, France, Germany, Italy, Spain and Sweden) are shown. In Austria the shadow economy labor force has reached in the years 1997-1998 500.000 to 750.000 or $16 \%$ of the official labor force (mean value). In Denmark the development of the 80s and 90s shows that the part of the Danish population engaged in the shadow economy ranged from $8.3 \%$ of the total labor force (in 1980) to $15.4 \%$ in 1994 - quite a remarkable increase of the shadow economy labor force; it almost doubled over 15 years. In France (in the years 1997/98) the shadow economy labor force reached a size of between 6 and $12 \%$ of the official labor force or in absolute figures between 1.4 and 3.2 million. In Germany this figure rose from 8 to $12 \%$ in 1974 to 1982 and to 22\% (18 millions) in the year 1997/98. For France and Germany this is again a very strong increase in the shadow economy labor force. In other countries the amount of the shadow economy labor force is quite large, too: in Italy 30-48\% (1997-1998), Spain 11.5-32\% (1997-1998) and Sweden 19.8 \% (1997-1998). In the European Union about 30 million people are engaged in shadow economy activities in the year 1997-1998 and in all European OECD-countries 48 million work illicitly.

These figures demonstrate that the shadow economy labor market is lively and may provide an explanation, why for example in Germany, one can observe such a high and persistent unemployment. In table 4 a first and preliminary calculation is done of the official GNP per capita and the shadow economy GDP per capita, shown in US-\$. Here one realizes immediately that in all countries investigated, the shadow economy GDP per capita is much higher - on average in all countries around $40 \%{ }^{8}{ }^{8}$ This clearly shows, that the productivity in the shadow economy quite likely is considerably higher then the official economy - a clear indication, that the work effort; i.e. the incentive to work effectively is stronger in the shadow economy. In general these very preliminary results clearly demonstrate that the shadow economy labor force has reached a remarkable size in the developed OECD-countries, too, even when the calculation still might have many errors, but again the picture shows, that the shadow economy labor market has reached a sizeable figure in most countries.

\footnotetext{
${ }^{7)}$ For developing countries some literature about the shadow labour market exists, e.g. the latest works by Dallago (1990), Pozo (1996), Loayza (1996), especially Chickering and Salahdine (1991).

8) This is an astonishing result, which has to be further checked, because in the official per capita GDP figures the whole economy is included with quite productive sectors (like electronics, steel, machinery, etc.) and the shadow economy figures traditionally contain mostly the service sectors (and the construction sector). Hence one could also expect exactly the opposite result, as the productivity in the service sector is usually much lower than in the above mentioned ones. Sources of error may be either an underestimation of the shadow economy labor force or an overestimation of the shadow economy in terms of value added.
} 
Table 4: Estimates of the Size of the "Shadow Economy Labor Force" and of the Official and Shadow Economy Productivity in Some OECD Countries 1974-1998

\begin{tabular}{|c|c|c|c|c|c|c|c|}
\hline Countries & Year & $\begin{array}{l}\text { Official GDP } \\
\text { per capita in } \\
\text { US- } \$ \text { (1) }\end{array}$ & $\begin{array}{l}\text { Shadow } \\
\text { Economy } \\
\text { GDP in US-\$ } \\
\text { per capita }\end{array}$ & $\begin{array}{l}\text { Size of the } \\
\text { Shadow Economy } \\
\text { (in \% of official } \\
\text { GDP) Currency } \\
\text { Demand } \\
\text { Approach }\end{array}$ & $\begin{array}{l}\text { Shadow } \\
\text { Economy } \\
\text { Labor Force in } \\
1000 \text { people }^{3)}\end{array}$ & $\begin{array}{l}\text { Shadow } \\
\text { Economy } \\
\text { Participants in } \\
\text { \% of official } \\
\text { Labor Force }\end{array}$ & $\begin{array}{l}\text { Sources of Shadow Economy Labour } \\
\text { Force }\end{array}$ \\
\hline Austria & $\begin{array}{l}90-91 \\
97-98\end{array}$ & $\begin{array}{l}20,636 \\
25,874\end{array}$ & $\begin{array}{l}25,382 \\
29,630\end{array}$ & $\begin{array}{l}\mathbf{5 . 4 7} \\
\mathbf{8 . 9 3}\end{array}$ & $\begin{array}{l}300-380 \\
500-750\end{array}$ & $\begin{array}{c}9.6 \\
16.0\end{array}$ & $\begin{array}{c}\text { Schneider }(1998) \text { and } \\
\text { own calculations }\end{array}$ \\
\hline Denmark & $\begin{array}{l}1980 \\
1986 \\
1991 \\
1994 \\
\end{array}$ & $\begin{array}{l}13,233 \\
18,496 \\
25,946 \\
34,441 \\
\end{array}$ & $\begin{array}{l}18,658 \\
26,356 \\
36,558 \\
48,562 \\
\end{array}$ & \begin{tabular}{c|}
8.6 \\
9.8 \\
11.2 \\
17.6 \\
\end{tabular} & $\begin{array}{l}250 \\
390 \\
410 \\
420 \\
\end{array}$ & $\begin{array}{c}8.3 \\
13.0 \\
14.3 \\
15.4 \\
\end{array}$ & $\begin{array}{c}\text { Mogensen, et. al. } \\
\text { (1995) } \\
\text { and own calculations }\end{array}$ \\
\hline France & $\begin{array}{l}1975-82 \\
1997-98 \\
\end{array}$ & $\begin{array}{l}12,539 \\
24,363\end{array}$ & $\begin{array}{l}17,542 \\
34,379\end{array}$ & $\begin{array}{c}6.9 \\
14.9\end{array}$ & $\begin{array}{c}800-1500 \\
1400-3200\end{array}$ & $\begin{array}{l}3.0-6.0 \\
6.0-12.0\end{array}$ & $\begin{array}{c}\text { De Grazia (1983) and } \\
\text { own calculations }\end{array}$ \\
\hline Germany & $\begin{array}{l}1974-82 \\
1997-98 \\
\end{array}$ & $\begin{array}{l}11,940 \\
26,080 \\
\end{array}$ & $\begin{array}{l}17,911 \\
39,634 \\
\end{array}$ & $\begin{array}{l}10.6 \\
14.7 \\
\end{array}$ & $\begin{array}{l}3000-4000 \\
7000-9000 \\
\end{array}$ & $\begin{array}{c}8.0-12.0 \\
19.0-23.0\end{array}$ & $\begin{array}{c}\text { De Grazia (1983), F. Schneider (1998b) } \\
\text { and own calculations } \\
\end{array}$ \\
\hline Italy & $\begin{array}{c}1979 \\
1997-98 \\
\end{array}$ & $\begin{array}{c}8,040 \\
20,361 \\
\end{array}$ & $\begin{array}{l}11,736 \\
29,425 \\
\end{array}$ & $\begin{array}{l}16.7 \\
27.3\end{array}$ & $\begin{array}{c}4000-7000 \\
6600-11400 \\
\end{array}$ & $\begin{array}{l}20.0-35.0 \\
30.0-48.0 \\
\end{array}$ & $\begin{array}{c}\text { Gaetani and d'Aragona (1979) and } \\
\text { own calculations } \\
\end{array}$ \\
\hline Spain & $\begin{array}{l}1979-80 \\
1997-98\end{array}$ & $\begin{array}{c}5,640 \\
13,791\end{array}$ & $\begin{array}{c}7,868 \\
19,927\end{array}$ & $\begin{array}{l}19.0 \\
23.1\end{array}$ & $\begin{array}{l}1250-3500 \\
1500-4200\end{array}$ & $\begin{array}{c}9.6-26.5 \\
11.5-32.3\end{array}$ & $\begin{array}{l}\text { Ruesga (1984) and } \\
\text { own calculations }\end{array}$ \\
\hline Sweden & $\begin{array}{c}1978 \\
1997-98\end{array}$ & $\begin{array}{l}15,107 \\
25,685\end{array}$ & $\begin{array}{l}21,981 \\
37,331 \\
\end{array}$ & $\begin{array}{l}13.0 \\
19.8\end{array}$ & $\begin{array}{c}750 \\
1150\end{array}$ & $\begin{array}{c}13.0-14.0 \\
19.8\end{array}$ & De Grazia (1983) and own calculations \\
\hline $\begin{array}{c}\text { European } \\
\text { Union }\end{array}$ & $\begin{array}{c}1978 \\
1997-98 \\
\end{array}$ & $\begin{array}{c}9,930 \\
22,179\end{array}$ & $\begin{array}{l}14,458 \\
32,226\end{array}$ & $\begin{array}{l}14.5 \\
19.6 \\
\end{array}$ & $\begin{array}{l}15000 \\
30000 \\
\end{array}$ & - & De Grazia (1983) and own calculations \\
\hline $\begin{array}{c}\text { OECD } \\
\text { (Europe) }\end{array}$ & $\begin{array}{c}1978 \\
1997-98 \\
\end{array}$ & $\begin{array}{c}9,576 \\
22,880\end{array}$ & $\begin{array}{l}14,162 \\
33,176\end{array}$ & $\begin{array}{l}15.0 \\
20.2 \\
\end{array}$ & $\begin{array}{l}26000 \\
48000 \\
\end{array}$ & - & De Grazia (1983) and own calculations \\
\hline
\end{tabular}

1) Source: OECD, Paris, various years

2) Source: Own calculations.

3 ) Estimated full-time jobs, including unregistered workers, illegal immigrants, and second jobs

4) In percent of the population aged 20-69, survey method. 


\subsection{Further results for the German-speaking Countries ${ }^{9}$}

In table 5 the development of the shadow economy for the countries Austria, Germany and Switzerland over time is presented.

Table 5: Size and Development of the Shadow Economy in Germany, Austria and Switzerland over 1975-2002 ${ }^{1)}$

\begin{tabular}{|c|c|c|c|c|c|c|}
\hline \multirow{3}{*}{ Year } & \multicolumn{6}{|c|}{$\begin{array}{c}\text { Size of the Shadow Economy (in \% of official GDP) using the Currency } \\
\text { Demand Approach }\end{array}$} \\
\hline & \multicolumn{2}{|c|}{ Germany } & \multicolumn{2}{|c|}{ Austria } & \multicolumn{2}{|c|}{ Switzerland } \\
\hline & in $\%$ & bill. $€$ & in \% & bill. $€$ & in $\%$ & bill. CHF \\
\hline 1975 & 5,75 & 29,6 & 2,04 & 0,9 & 3,20 & 12 \\
\hline 1980 & 10,80 & 80,2 & 2,69 & 2,0 & 4,90 & 14 \\
\hline 1985 & 11,20 & 102,3 & 3,92 & 3,9 & 4,60 & 17 \\
\hline 1990 & 12,20 & 147,9 & 5,47 & 7,2 & 6,20 & 22 \\
\hline 1995 & 13,90 & $241,1^{2)}$ & 7,32 & 12,4 & 6,89 & 25 \\
\hline 1996 & 14,50 & $257,6^{2)}$ & 8,32 & 14,6 & 7,51 & 27 \\
\hline 1997 & 15,00 & $274,7^{2)}$ & 8,93 & 16,0 & 8,04 & 29 \\
\hline 1998 & 14,80 & $280,7^{2)}$ & 9,09 & 16,9 & 7,98 & 30 \\
\hline 1999 & 15,51 & $301,8^{2)}$ & 9,56 & 18,2 & 8,34 & 32 \\
\hline 2000 & 16,03 & $322,3^{2)}$ & 10,07 & 19,8 & 8,87 & 35 \\
\hline$(2001)^{3)}$ & 16,00 & $329,8^{2)}$ & 10,52 & 21,1 & 9,28 & $\mathbf{3 7 , 5}$ \\
\hline$(2002)^{3)}$ & 16,49 & $350,4^{2)}$ & 10,69 & 21,8 & 9,48 & 38,7 \\
\hline
\end{tabular}

1) Explanations: The size of the shadow economy can only roughly be compared between the three countries, as the currency demand equation is specified differently between the three countries and the independent "cause" variables (taxation regulation, etc.) are not the same in all three countries.

2) From 1995 values for the United Germany.

3) Forecast, as official values are not available.

Source: Own calculations.

If one considers first Germany, one realises, that in the year 1975 the German shadow economy had a size of $5.75 \%$ (of official GDP) which rose to $16.49 \%$ of official GDP in

\footnotetext{
9) These part closely follows Mummert and Schneider (2002).
} 
the year 2002. In Austria in the year 1975 the shadow economy was 2.04\% and increased to $10.69 \%$ in the year 2002. A similar movement took place in Switzerland where the shadow economy in the year 1975 was $3.2 \%$ and rose to $9.48 \%$ in the year 2002 . In all three German-speaking countries one observes a strong increase of the shadow economy, but by far the strongest in Germany, where one now observe a shadow economy of 350,4 billion $€$ in the year 2002 .

The figures presented above allow for the assumption of constantly rising shadow economic activities in Germany. Measurement results taken via microeconomic approaches point in the same direction: Several estimates of the size of the shadow economic labor force in Europe underline the (probably growing) relevance of shadow economic activities within economic systems, too. ${ }^{10)}$ In a survey conducted by telephone interviews in March 1998 in Germany by IFAK with a representative sample of the responses of 1.000 persons $22 \%$ admitted that they indeed had been working in the shadow economy. ${ }^{11)}$ Though microeconomic measurement approaches give information with respect to the overall size of shadow economic activities it is especially their detailed information on the different activities and on the people involved which are of interest in the present context. Shadow economic activities seem to form a natural part of market activities in Germany: Again in the IFAK-survey only 31,2 \% of the respondents thought that nearly none of their friends or acquaintances had at least once been buying goods or services in the shadow economy. Instead, more than $60 \%$ assumed that at least a quarter of their friends and acquaintances $(23,1 \%)$ up to almost all $(13,2 \%)$ had once or several times accepted the offer of black labor.

But who are the people offering black labor and what kind of labor is involved? Most surveys point to the average supplier of black labor holding a regular job in the official economy and thus being only part-time involved in shadow economic activities. ${ }^{12)}$ Around $60 \%$ of the suppliers of black labor in the IFAK-survey worked in the official economy, too. Still, it is generally assumed that despite most of the black labor being offered by official jobholders unemployed, students and social welfare recipients are relatively more

\footnotetext{
10) De Grazia, 1983; Schneider \& Enste, 2000b.

${ }^{11)}$ The survey was undertaken in the name of B.A.C. Burda, Munich. I would like to thank Burda Press for their very co-operative behavior. Some of the empirical results of the IFAK-study can be found in Focus, 1998. With only 26.3 percent of the households refusing to be interviewed, the response rate is rather good. This is especially true if this figure is compared with the non-response rate of other surveys e.g. in Canada 48 percent (see Lemieux, Fortin \& Fréchette, 1994), in the Netherlands (between 50 and 60 percent) and in Denmark (see Mogensen, et al., 1995: 7-9). For a detailed discussion on quality matters see Mummert and Schneider (2002).

${ }^{12)}$ See for instance Dallago, 1990; Lemieux, Fortin \& Fréchette, 1994; Mogensen, et al., 1995.
} 
engaged in shadow economic activities than regular job holders (see e.g. Lemieux, Fortin \& Fréchette, 1994).

In congruence with other empirical results on shadow economies (see e.g. Dallago, 1990) shadow economic activities in Germany seem to be mostly concentrated in the areas of house construction, renovation, car repairs and servicing. Most of these services presuppose a certain income level. Correspondingly, the demand of black labor has its roots rather in the middle class than in low income groups (see also Gretschmann, 1984: $115)$.

In addition to the empirical results presented so far, the already mentioned IFAK-survey holds some interesting information on shadow economic activities in East and West Germany, too: The representative sample includes the responses of 797 persons in West Germany and 170 in East Germany aged 14 years and over. Only $12.9 \%$ of the respondents living in the Eastern part of Germany admitted that they had been working in the shadow economy in contrast to $24.5 \%$ in West Germany (see table 6).

Table 6: Supply of shadow economic activities

"Honestly, have you ever done Schwarzarbeit?"

\begin{tabular}{|l|l|l|}
\hline & Western Germans & Eastern Germans \\
\hline Yes & $24.5 \%$ & $12.9 \%$ \\
\hline No & $73.5 \%$ & $85.3 \%$ \\
\hline No response & $2.0 \%$ & $1.8 \%$ \\
\hline
\end{tabular}

East-West differences statistically significant: 2-Tailed P $0.0023 ; Z-3.0515$.

Source: IFAK, 1998, own calculations

This significant difference between the West- and East-Germany with respect to the extent of black labour holds for the amount of purchases of goods and services in the shadow economy, as well: Being asked to assess how many people in their circle of acquaintances and friends have demanded services in the shadow economy (at least once) the respondents answered in the following way (see table 7).

Table 7: Demand of black labour in the circle of acquaintances and friends (in percent) "How many of your friends or acquaintances do you think have made use of Schwarzarbeit at least once?"

\begin{tabular}{|l|l|l|}
\hline & Western Germans & Eastern Germans \\
\hline Almost none of them & $25.5 \%$ & $56.5 \%$ \\
\hline About $1 / 4$ of them & $23.2 \%$ & $21.8 \%$ \\
\hline About the half of them & $18.9 \%$ & $11.8 \%$ \\
\hline about 3 of them & $10.2 \%$ & $2.4 \%$ \\
\hline All or almost all & $15.7 \%$ & $2.9 \%$ \\
\hline I do not know & $6.5 \%$ & $4.7 \%$ \\
\hline
\end{tabular}

East-West differences statistically significant: 2-Tailed P $0.0001 ; Z-7.2749$.

Source: IFAK, 1998, own calculations 
More than $50 \%$ of the respondents in East Germany were sure that their acquaintances and friends refrained from purchasing goods and services in the shadow economy compared to only $25 \%$ in the West. A similar contrast between the actions of people in East- and West-Germany can be noted concerning a high involvement in shadow economic activities. Whereas $26 \%$ of the respondents in West-Germany assessed that most (about three quarter) up to nearly all of their acquaintances and friends had at least once accepted buying goods and services in the shadow economy only $5 \%$ in the East answered the same way. Again, comparing the answers of East- and West-Germans with respect to their differences, we get a statistical significance on the 0.01 level.

Interestingly, there seems to be also a lesser willingness of suppliers in the eastern official economy to offer also unreported services to their clients (see table 8).

\section{Table 8: Unsolicited offer of black labour (in percent)}

"Has anyone ever made you an unsolicited offer to provide you with a gray market service rather than a legal one?"

\begin{tabular}{|l|l|l|}
\hline & Western Germans & Eastern Germans \\
\hline Yes, once & $9,5 \%$ & $12,4 \%$ \\
\hline Yes, repeatedly & $32.7 \%$ & $12.4 \%$ \\
\hline No, never & $56.0 \%$ & $74.7 \%$ \\
\hline No response & $1.8 \%$ & $0.6 \%$ \\
\hline
\end{tabular}

East-West differences statistically significant: 2 Tailed P $0.0015 ; Z-3.1655$.

Source: IFAK, 1998, own calculations

Especially with respect to the answer "Yes, repeatedly" there is a difference between the western and the eastern part of Germany, because in East Germany only $12.4 \%$ made this experience compared to $32.7 \%$ in the West.

In table 9 the shadow economy of the German countries („Länder“) is presented ${ }^{13)}$. This has been done to provide further empirical evidence that the shadow economy in the former GDR (or „Neue Bundesländer“) is lower then in West-Germany (or in the „Alten Bundesländer") respectively. Table 8 confirms, that on average the East-German„Bundesländer" have a lower shadow economy compared to the overall shadow economy in Germany and to the shadow economies of most West-German countries. For example, for the year 1999 the shadow economy of East-Berlin is $-1.6 \%$ below the average shadow economy, the one of Sachsen of $-1.1 \%$ and the one of Thüringen $-1.5 \%$. In general these results show, that the shadow economy in Germany is growing, that there are some

13) The estimation method is explained in detail in Schneider (2001). 
differences between East- and West-Germany, with the result that the shadow economy in the East-German "Länder" is lower.

Table 9: The Size of the Shadow Economy of the German „Länder" of the years 1995 and 1999

\begin{tabular}{|c|c|c|c|}
\hline \multirow[t]{2}{*}{ German „Länder“6 } & \multicolumn{2}{|c|}{$\begin{array}{c}\text { Size of the Shadow Economy } \\
\text { in mio. } € \text { and in \% of official } \\
\text { GDP }\end{array}$} & \multirow{2}{*}{$\begin{array}{c}\text { Difference from the size of } \\
\text { total Germany } \\
\text { (in \% of GDP) of the year } \\
1999\end{array}$} \\
\hline & 1995 & 1999 & \\
\hline Baden-Württemberg & $\begin{array}{r}31.064 \\
12,55 \\
\end{array}$ & $\begin{array}{r}37.777 \\
13,38 \\
\end{array}$ & $-2,15$ \\
\hline Bayern & $\begin{array}{r}39.034 \\
13,47\end{array}$ & $\begin{array}{r}47.904 \\
14,5 \\
\end{array}$ & $-1,03$ \\
\hline Berlin West & $\begin{array}{r}10.280 \\
17,99 \\
\end{array}$ & $\begin{array}{r}12.290 \\
21,73 \\
\end{array}$ & $+6,20$ \\
\hline Berlin Ost & \begin{tabular}{r|}
1.934 \\
10,1 \\
\end{tabular} & $\begin{array}{l}2.693 \\
13,92 \\
\end{array}$ & $-1,61$ \\
\hline Brandenburg & $\begin{array}{l}4.532 \\
13,24 \\
\end{array}$ & \begin{tabular}{|l|}
5.659 \\
14,12 \\
\end{tabular} & $-1,41$ \\
\hline Bremen & \begin{tabular}{l|}
2.707 \\
13,99 \\
\end{tabular} & $\begin{array}{l}3.474 \\
16,48 \\
\end{array}$ & $+0,95$ \\
\hline Hamburg & $\begin{array}{l}6.970 \\
10,45 \\
\end{array}$ & $\begin{array}{l}9.097 \\
13,08 \\
\end{array}$ & $-2,45$ \\
\hline Hessen & $\begin{array}{r}19.298 \\
11,74 \\
\end{array}$ & $\begin{array}{r}24.898 \\
14,2 \\
\end{array}$ & $-1,33$ \\
\hline Mecklenburg-Vorpommern & \begin{tabular}{l|}
3.460 \\
15,28 \\
\end{tabular} & $\begin{array}{l}4.343 \\
15,49 \\
\end{array}$ & $-0,04$ \\
\hline Niedersachsen & $\begin{array}{r}25.145 \\
16,65 \\
\end{array}$ & $\begin{array}{r}31.555 \\
18,36 \\
\end{array}$ & $+2,83$ \\
\hline Nordrhein-Westfalen & $\begin{array}{r}56.647 \\
14,67 \\
\end{array}$ & $\begin{array}{r}71.747 \\
16,56 \\
\end{array}$ & $+1,03$ \\
\hline Rheinland-Pfalz & $\begin{array}{r}11.271 \\
14,86 \\
\end{array}$ & $\begin{array}{r}14.230 \\
16,46 \\
\end{array}$ & $+0,93$ \\
\hline Saarland & $\begin{array}{r}3.241 \\
14,9 \\
\end{array}$ & $\begin{array}{l}4.111 \\
17,28 \\
\end{array}$ & $+1,75$ \\
\hline Sachsen & $\begin{array}{l}8.239 \\
14,19 \\
\end{array}$ & $\begin{array}{r}10.279 \\
14,47 \\
\end{array}$ & $-1,06$ \\
\hline Sachsen-Anhalt & $\begin{array}{l}5.020 \\
14,99 \\
\end{array}$ & $\begin{array}{l}6.216 \\
15,46 \\
\end{array}$ & $-0,07$ \\
\hline Schleswig-Holstein & $\begin{array}{l}8.619 \\
15,98 \\
\end{array}$ & $\begin{array}{r}11.087 \\
17,81 \\
\end{array}$ & $+2,28$ \\
\hline Thüringen & $\begin{array}{l}4.425 \\
14,74 \\
\end{array}$ & \begin{tabular}{l|}
5.375 \\
14,03 \\
\end{tabular} & $-1,50$ \\
\hline All countries together & $\begin{array}{r}241.887 \\
13,97 \\
\end{array}$ & $\begin{array}{r}302.736 \\
15,53 \\
\end{array}$ & 0,0 \\
\hline
\end{tabular}

Source: Schneider 2001. 


\section{The Main Causes of the Increase of the Shadow Economy}

\subsection{Increase of the Tax and Social Security Contribution Burdens}

In almost all studies ${ }^{14)}$ it has been found out, that the increase of the tax and social security contribution burdens is one of the main causes for the increase of the shadow economy. Since taxes affect labor-leisure choices, and also stimulate labor supply in the shadow economy, or the untaxed sector of the economy, the distortion of this choice is a major concern of economists. The bigger the difference between the total cost of labor in the official economy and the after-tax earnings (from work), the greater is the incentive to avoid this difference and to work in the shadow economy. Since this difference depends broadly on the social security system and the overall tax burden, they are key features of the existence and the increase of the shadow economy. But even major tax reforms with major tax rate deductions will not lead to a substantial decrease of the shadow economy. They will only be able to stabilize the size of the shadow economy and avoid a further increase. Social networks and personal relationships, the high profit from irregular activities and associated investments in real and human capital are strong ties which prevent people from transferring to the official economy. For Canada, Spiro (1993) expected similar reactions of people facing an increase in indirect taxes (VAT, GST). After the introduction of the GST in 1991 - in the midst of a recession - , the individuals suffering economic hardship because of the recession turned to the shadow economy, which led to a substantial loss in tax revenue. "Unfortunately, once this habit is developed, it is unlikely that it will be abandoned merely because economic growth resumes.“ (Spiro 1993 p. 255). They may not return to the formal sector, even in the long run. This fact makes it even more difficult for politicians to carry out major reforms because they may not gain a lot from them. ${ }^{15)}$

In neoclassical models the most important factor is the marginal tax rate. The higher the marginal tax rate, the greater is the substitution effect and the bigger the distortion of the labor-leisure decision. Especially when taking into account that the individual can also receive income in the shadow economy, the substitution effect is definitely larger than the

\footnotetext{
14) See Thomas (1992); Lippert and Walker (1997); Schneider (1994a, 1994b, 1997, 1998, 2000); Johnson, Kaufmann, and Zoido-Lobatón (1998a,1998b); Tanzi (1999) and Giles (1999a) just to quote a few recent ones.

${ }^{15)}$ See Schneider $(1994 b, 1998 b)$ for a similar result of the effects of a major tax reform in Austria on the shadow economy. Schneider shows that a major reduction in the direct tax burden did not lead to a major reduction in the shadow economy. Because legal tax avoidance was abolished and other factors, like regulations, were not changed; hence for a considerable part of the tax payers the actual tax and regulation burden remained unchanged.
} 
income effect ${ }^{16)}$ and, hence, the individual works less in the official sector. The overall efficiency of the economy is, therefore (ceteris paribus) lower and the distortion leads to a welfare loss (according to official GNP and taxation.) But the welfare might also be viewed as increasing, if the welfare of those, who are working in the shadow economy, were taken into account, too. ${ }^{17)}$

Empirical results of the influence of the tax burden on the shadow economy is provided in the studies of Schneider (1994b, 2000) and Johnson, Kaufmann and Zoido-Lobatón (1998a, 1998b); they all found strong evidence for the general influence of taxation on the shadow economy. This strong influence of indirect and direct taxation on the shadow economy will be further demonstrated by discussing empirical results in the case of Austria and the Scandinavian countries. For Austria the driving force for the shadow economy activities is the direct tax burden (including social security payments), it has the biggest influence, followed by the intensity of regulation and complexity of the tax system. A similar result has been achieved by Schneider (1986) for the Scandinavian countries (Denmark, Norway and Sweden). In all three countries various tax variables (average direct tax rate, average total tax rate (indirect and direct tax rates)) and marginal tax rates have the expected positive sign (on currency demand) and are highly statistically significant. Similar results are reached by Kirchgaessner $(1983,1984)$ for Germany and by Kloveland (1984) for Norway and Sweden.

Several other recent studies provide further evidence of the influence of income tax rates on the shadow economy: Cebula (1997), using Feige data for the shadow economy, found evidence of the impact of government income tax rates, IRS audit probabilities, and IRS penalty policies on the relative size of the shadow economy in the United States. Cebula concludes that a restraint of any further increase of the top marginal income tax rate may at least not lead to a further increase of the shadow economy, while increased IRS audits and penalties might reduce the size of the shadow economy. His findings indicate that there is generally a strong influence of state activities on the size of the shadow economy: For example, if the marginal federal personal income tax rate increases by one percentage point, ceteris paribus, the shadow economy rises by 1.4 percentage points. In another investigation, Hill and Kabir (1996) found empirical evidence that marginal tax rates are more relevant than average tax rates, and that a substitution of direct taxes by indirect taxes seems unlikely to improve tax compliance. Further evidence on the effect of

\footnotetext{
${ }^{16)}$ If leisure is assumed to be a normal good.
} 
taxation on the shadow economy is presented by Johnson, Kaufmann, and Zoido-Lobatón (1998b), who come to the conclusion that it is not higher tax rates per se that increase the size of the shadow economy, but the ineffective and discretionary application of the tax system and the regulations by governments. Their finding, that there is a negative correlation $^{18)}$ between the size of the unofficial economy and the top (marginal) tax rates, might be unexpected. But since other factors like tax deductibility, tax relives, tax exemptions, the choice between different tax systems, and various other options for legal tax avoidance were not taken into account, it is not all that surprising. ${ }^{19)}$ On the other side Johnson, Kaufmann and Zoido-Lobatón (1998b) find a positive correlation between the size of the shadow economy and the corporate tax burden. They come to the overall conclusion that there is a large difference between the impact of either direct taxes or the corporate tax burden. Institutional aspects, like the efficiency of the administration, the extent of control rights held by politicians and bureaucrats, and the amount of bribery and especially corruption, therefore, play a major role in this "bargaining game" between the government and the taxpayers.

In table 10 it is tried to provide an explanation of the different sizes of the shadow economies of some of the 21 OECD countries by comparing the overall tax and social security contributions with the size of the shadow economy of the different countries for the year $1996 .^{20)}$

\section{Table 10}

With the exception of Spain (shadow economy 22.9\%, tax and social security burden $67.2 \%$ ), Greece, Italy, Belgium and Sweden, who have the largest shadow economies in 1996 also have the highest tax and social security burden $(72.3,72.9,76.0$ and $78.6 \%)$,

\footnotetext{
${ }^{17)}$ See Thomas (1992) p. 134-7.

${ }^{18)}$ The higher the top marginal tax rate, the lower the size of the shadow economy.

${ }^{19)}$ Friedman, Johnson, Kaufmann and Zoido-Lobatón (1999) found a similar result in a cross country analysis that higher tax rates are associated with less official activity as percent of GDP. They argue entrepreneurs go underground not to avoid official taxes but they want to reduce the burden of bureaucracy and corruption. However looking at their empirical (regression) results the finding that higher tax rates are correlated with a lower share of the unofficial economy is not very robust and in most cases, using different tax rates, they do not find a statistically significant result.

${ }^{20)}$ In almost all studies the rise of the tax and social security contribution burdens is one of the most important causes of the increase of the shadow economy. Compare for example Frey and Pommerehne (1984), Lipert and Walker (1997), Schneider (1994a, 1994b, 1997, 2000), Thomas (1992, 1999), Tanzi (1999), Giles (1999a) and Schneider and Enste (2000).
} 
whereas the countries like Switzerland and U.S., who have the lowest overall tax and social security burden (39.7 and 41.4\%) they have the lowest shadow economies with 7.5 and $8.8 \%$, too! Of course, there are exceptions, like the United Kingdom and Austria with a quite high overall tax and social security burden (54.9 and 70.4\%) and a quite low shadow economy (13.1 and $8.3 \%$ ), but the overall pictures seems to fit, the higher the overall social security and tax burden, the higher the shadow economy, ceteris paribus. The strong positive relationship that a rising tax and social security contribution burdens cause a higher shadow economy, is also demonstrated in figures 2.1 and 2.2

\section{Figures 10.1 and 10.2}

If one calculates the correlation coefficient between the tax and social security contribution burden and the size of the shadow economy, the coefficient has a value of 0.61 , which is clearly statistically significant from zero. 
Table 10: The Size of the Shadow Economy and the Burden of Taxes and Social Security Contributions in OECD countries in the year 1996

\begin{tabular}{|c|c|c|c|c|c|c|c|c|}
\hline Country & $\begin{array}{l}\text { Size of the } \\
\text { shadow } \\
\text { economy (in } \\
\% \text { of GDP) }\end{array}$ & $\begin{array}{c}\text { Value added } \\
\text { tax rate (in } \\
\%^{1)}\end{array}$ & $\begin{array}{c}\text { Average } \\
\text { direct tax } \\
\text { rate } \\
(\text { in \%) }\end{array}$ & $\begin{array}{c}\begin{array}{c}\text { Social security } \\
\text { contributions }\end{array} \\
\text { by employees } \\
\text { rate }{ }^{3)} \\
\text { (in \%) } \\
\\
1996 \\
\text { (4) } \\
\end{array}$ & $\begin{array}{c}\text { Social security } \\
\text { contributions } \\
\text { by employers } \\
\text { rate } \\
\text { (in \%) } \\
\\
1996 \\
\text { (5) } \\
\end{array}$ & 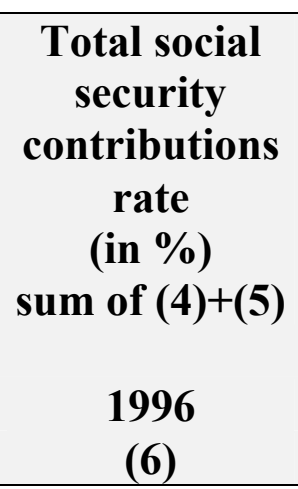 & \begin{tabular}{|c|} 
Total social \\
security \\
contributions + \\
direct tax \\
burden: sum \\
$(4)+(5)+(3)$ \\
$($ in \%) \\
1996 \\
$(7)$ \\
\end{tabular} & $\begin{array}{c}\text { Total tax } \\
\text { and social } \\
\text { security } \\
\text { burden: } \\
\text { sum } \\
(2)+(3)+ \\
(4)+(5) \\
1996 \\
(8) \\
\end{array}$ \\
\hline Greece & 28.5 & 18.0 & 11.0 & 15.8 & 27.5 & 43.3 & 54.3 & 72.3 \\
\hline Italy & 27.0 & 19.0 & 12.0 & 9.9 & 32.0 & 41.9 & 53.9 & 72.9 \\
\hline Spain & 22.9 & 16.0 & 13.0 & 6.6 & 31.6 & 38.2 & 51.2 & 67.2 \\
\hline Belgium & 21.9 & 21.0 & 19.0 & 10.0 & 26.0 & 36.0 & 55.0 & 76.0 \\
\hline Sweden & 19.2 & 25.0 & 20.0 & 4.0 & 29.6 & 33.6 & 53.6 & 78.6 \\
\hline Norway & 18.9 & 23.0 & 19.0 & 7.0 & 12.8 & 19.8 & 38.8 & 61.8 \\
\hline Denmark & 18.3 & 25.0 & 36.0 & 9.0 & 0.0 & 9.0 & 45.0 & 70.0 \\
\hline Ireland & 15.9 & 21.0 & 20.0 & 7.2 & 12.3 & 19.5 & 39.5 & 60.5 \\
\hline Canada & 14.6 & 7.0 & 21.0 & 7.0 & 8.0 & 15.0 & 36.0 & 43.0 \\
\hline Germany & 14.5 & 15.0 & 18.0 & 16.1 & 16.1 & 32.2 & 50.2 & 65.2 \\
\hline France & 14.3 & 20.6 & 6.0 & 13.0 & 31.0 & 44.0 & 50.0 & 70.6 \\
\hline Netherlands & 14.0 & 17.5 & 10.0 & 31.0 & 8.8 & 39.8 & 49.8 & 67.3 \\
\hline U.K. & 13.1 & 17.5 & 16.0 & 10.7 & 10.2 & 21.4 & 37.4 & 54.9 \\
\hline USA & 8.8 & 3.0 & 17.0 & 7.6 & 13.8 & 21.4 & 38.4 & 41.4 \\
\hline Austria & 8.3 & 20.0 & 8.0 & 18.2 & 24.2 & 42.4 & 50.4 & 70.4 \\
\hline Switzerland & 7.5 & 6.5 & 10.0 & 11.6 & 11.6 & 23.2 & 33.2 & 39.7 \\
\hline
\end{tabular}

1) Rates of the year 1996; USA: Average sales tax

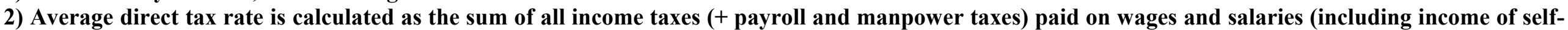
employed) divided by gross labor costs of an average income earner in the respective country.

3) The rate is calculated on the basis of the annual gross earnings of an average income earner in the respective country.

Source: Own calculations and OECD-working paper 176, 1997, Paris. 
Figur 10.1: Size of the Shadow Economy vs Total Soc. Security

Contributions + Direct Tax Burden*, Year 1996

(Correlation Coefficient with AT $=0,61$, without $A T=0,72$ )

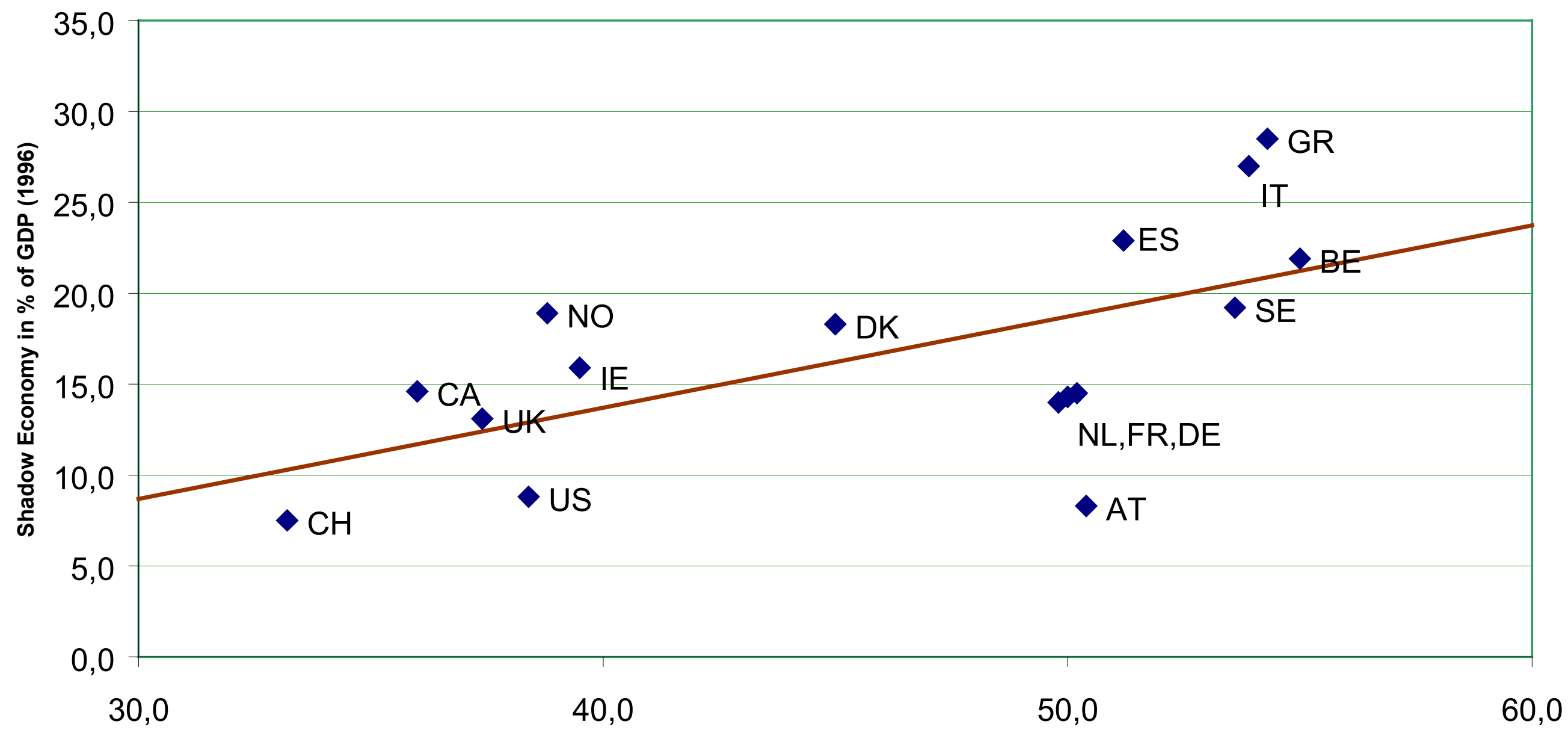

Total Soc. Security Contributions + Direct Tax Burden in \%

* Sum of all income taxes paid on wages and salaries (including income of self-employed) divided by gross labor costs of an average income earner 
Fiaur 10.2: Size of the Shadow Economy vs

Total Tax* and Soc. Security Burden, Year 1996

(Correlation Coefficient with AT $=0,62$, without AT $=0,74$ )

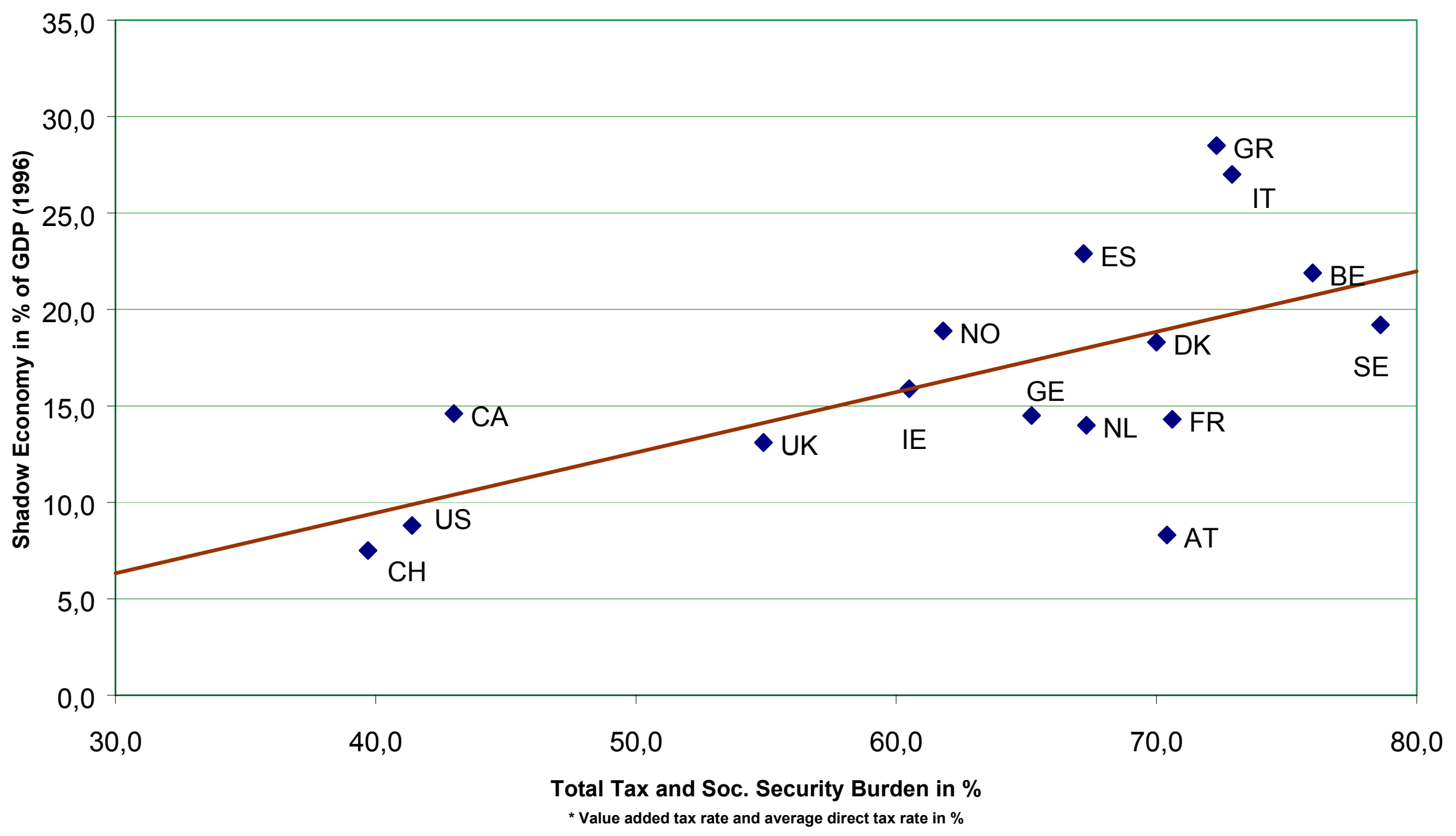




\subsection{Intensity of Regulations}

The increase of the intensity of regulations (often measured in the numbers of laws and regulations, like licenses requirements) is another important factor, which reduces the freedom (of choice) for individuals engaged in the official economy. ${ }^{21)}$ One can think of labor market regulations, trade barriers, and labor restrictions for foreigners. Johnson, Kaufmann, and Zoido-Lobatón (1998b) find an overall significant empirical evidence of the influence of (labor) regulations on the shadow economy, the impact is clearly described and theoretically derived in other studies, e.g. for Germany (Deregulation Commission 1990/91). Regulations lead to a substantial increase in labor costs in the official economy. But since most of these costs can be shifted on the employees, these costs provide another incentive to work in the shadow economy, where they can be avoided. Empirical evidence supporting the model of Johnson, Kaufmann, and Shleifer (1997), which predicts, inter alia, that countries with more general regulation of their economies tend to have a higher share of the unofficial economy in total GDP, is found in their empirical analysis. A one-point increase of the regulation index (ranging from 1 to 5 , with $5=$ the most regulation in a country), ceteris paribus, is associated with an 8.1 percentage point increase in the share of the shadow economy, when controlled for GDP per capita (Johnson et. al. (1998b), p. 18). They conclude that it is the enforcement of regulation, which is the key factor for the burden levied on firms and individuals, and not the overall extent of regulation - mostly not enforced - which drive firms into the shadow economy. Friedman, Johnson, Kaufmann and Zoido-Lobaton (1999) reach a similar result. In their study every available measure of regulation is significantly correlated with the share of the unofficial economy and the sign of the relationship is unambiguous: more regulation is correlated with a larger shadow economy. A one point increase in an index of regulation (ranging from 1-5) is associated with a $10 \%$ increase in the shadow economy for 76 developing, transition and developed countries.

These findings demonstrate that governments should put more emphasis on improving enforcement of laws and regulations, rather than increasing their number. Some governments, however, prefer this policy option (more regulations and laws), when trying

\footnotetext{
${ }^{21)}$ See for a (social) psychological, theoretical foundation of this feature, Brehm $(1966,1972)$, and for a (first) application to the shadow economy, Pelzmann (1988).
} 
to reduce the shadow economy, mostly because it leads to an increase in power of the bureaucrats and to a higher rate of employment in the public sector.

\section{Some Methods to Estimate the Size of the Shadow Economy ${ }^{22}$}

As has already been mentioned in chapter 2 to undertake attempts to measure the size of a shadow economy is a difficult and challenging task. In this chapter a short overview is given about the current knowledge of some procedures to estimate the shadow economy. To measure the size and development of the shadow economy three different types of methods are most widely used. They are briefly discussed in the following three subsections.

\subsection{Direct Approaches}

These are micro approaches which employ either well designed surveys and samples based on voluntary replies or tax auditing and other compliance methods. Sample surveys designed for estimation of the shadow economy are widely used in a number of countries $^{23)}$ to measure the shadow economy. The main disadvantage of this method is that it presents the flaws of all surveys: average precision and results depend greatly on the respondents willingness to cooperate. It is difficult to asses the rise of the undeclared work from a direct questionnaire. Most interviewed hesitate to confess a fraudulent behavior and quite often responses are rarely reliable so that it is difficult, from this type of answers, to calculate a real estimate - in monetary terms - of the extend of undeclared work. The main advantage of this method lies in the detailed information about the structure of the shadow economy, but the results from these kinds of surveys are very sensitive to the way the questionnaire is formulated ${ }^{24)}$.

Estimates of the shadow economy can also be based on the discrepancy between income declared for tax purposes and that measured by selective checks. Fiscal auditing programs

\footnotetext{
${ }^{22)}$ This chapter closely follows Schneider and Enste (2000); they give also a more detailed description of all methods used to estimate the shadow economy including a critical discussion of them.

${ }^{23)}$ The direct method of voluntary sample surveys has been extensively used for Norway by Isachsen, Klovland and Strom (1982), and Isachsen and Strom (1985). For Denmark this method is used by Mogensen (et. al., 1995) in which they report ,estimates“ of the shadow economy of 2.7 percent of GDP for 1989, of 4.2 percent of GDP for 1991, of 3.0 percent of GDP for 1993 and of 3.1 percent of GDP for 1994.

${ }^{24)}$ The advantages and disadvantages of this method are extensively dealt by Mogensen et. al (1995) in their
} 
have been particularly effective in this regard. Designed to measure the amount of undeclared taxable income, they have been used to calculate the shadow economy in several countries. ${ }^{25)}$ A number of difficulties beset this approach. Firstly, using tax compliance data is equivalent to using a (possibly biased) sample of the population. However, since in general a selection of tax payers for tax audit is not random, but based on properties of submitted (tax) returns which indicate a certain likelihood of (tax) fraud, such a sample is not a random one of the whole population. This factor is likely to bias compliance - based estimates of the black economy. Secondly, estimates based on tax audits reflect that portion of black economy income which the authorities succeeded in discovering and this is likely to be only a fraction of hidden income.

A further disadvantage of the two direct methods (surveys and tax auditing) is that they lead only to point estimates in time. Moreover, it is unlikely that they capture all „shadow“ activities, so they can be seen as providing lower bound estimates. They are unable (at least at present) to provide estimates of the development and growth of the shadow economy over a longer period of time. As already argued, they have, however, at least one considerable advantage - they can provide detailed information about shadow economy activities and the structure and composition of those who work in the shadow economy.

\subsection{Indirect Approaches}

These approaches, which are also called ,indicator“ approaches, are mostly macroeconomic ones and use various economic and other indicators that contain information about the development of the shadow economy (over time). Currently there are five indicators which leave some ,traces“ of the development of the shadow economy: ${ }^{26)}$

\footnotetext{
excellent and very carefully done investigation.

${ }^{25}$ In the United States, IRS (1979, 1983), Simon and Witte (1982), Witte (1987), Clotefelter (1983), and Feige (1986). For a more detailed discussion, see Dallago (1990) and Thomas (1992).

26) Out of these five indicator approaches only two are discussed here, which have been used; hence the discrepancy between national expenditure and income method, the discrepancy between official and actual labor force and the transactions approach are not presented here; compare Schneider and Enste (2000) for them.
} 


\subsubsection{The Currency Demand Approach}

The currency demand approach was first used by Cagan (1958), who calculated a correlation of the currency demand and the tax pressure (as one cause of the shadow economy) for the United States over the period 1919 to 1955. 20 years later, Gutmann (1977) used the same approach, but did not use any statistical procedures; instead he „only“ looked at the ratio between currency and demand deposits over the years 1937 to 1976.

Cagan's approach was further developed by Tanzi (1980, 1983), who econometrically estimated a currency demand function for the United States for the period 1929 to 1980 in order to calculate the shadow economy. His approach assumes that shadow (or hidden) transactions are undertaken in the form of cash payments, so as to leave no observable traces for the authorities. An increase in the size of the shadow economy will therefore increase the demand for currency. To isolate the resulting „excess“ demand for currency, an equation for currency demand is econometrically estimated over time. All conventional possible factors, such as the development of income, payment habits, interest rates, and so on, are controlled for. Additionally, such variables as the direct and indirect tax burden, government regulation and the complexity of the tax system, which are assumed to be the major factors causing people to work in the shadow economy, are included in the estimation equation. ${ }^{27)}$

The „excess“ increase in currency, which is the amount unexplained by the conventional or normal factors (mentioned above) is then attributed to the rising tax burden and the other reasons leading people to work in the shadow economy. Figures for the size and development of the shadow economy can be calculated in a first step by comparing the difference between the development of currency when the direct and indirect tax burden (and government regulations) are held at its lowest value, and the development of currency with the current (much higher) burden of taxation and government regulations. Assuming in a second step the same income velocity for currency used in the shadow economy as for legal M1 in the official economy, the size of the shadow economy can be computed and compared to the official GDP.

\footnotetext{
27) The estimation of such a currency demand equation has been criticized by Thomas (1999) but part of this criticism has been considered by the work of Giles (1999a, 1999b) and Bhattacharyya (1999), who both use the latest econometric technics.
} 
The currency demand approach is one of the most commonly used approaches. It has been applied to many OECD countries, ${ }^{28)}$ but has nevertheless been criticized on various grounds. ${ }^{29)}$ The most commonly raised objections to this method are:

(i) Not all transactions in the shadow economy are paid in cash. Isachsen and Strom (1985) used the survey method to find out that in Norway, in 1980, roughly 80 percent of all transactions in the hidden sector were paid in cash. The size of the total shadow economy (including barter) may thus be even larger than previously estimated.

(ii) Most studies consider only one particular factor, the tax burden, as a cause of the shadow economy. But others (such as the impact of regulation, taxpayers' attitudes toward the state, ,tax morality“ and so on) are not considered, because reliable data for most countries is not available. If, as seems likely, these other factors also have an impact on the extent of the hidden economy, it might again be higher than reported in most studies. ${ }^{30)}$

(iii) A further weakness of this approach, at least when applied to the United States, is discussed by Garcia (1978), Park (1979), and Feige (1996), who point out that increases in currency demand deposits are due largely to a slowdown in demand deposits rather than to an increase in currency caused by activities in the shadow economy.

(iv) Blades (1982) and Feige (1986, 1996), criticize Tanzi's studies on the grounds that the US dollar is used as an international currency. Tanzi should have considered (and controlled for) the US dollars, which are used as an international currency and held in cash abroad. ${ }^{31)}$ Moreover, Frey and Pommerehne (1984) and

\footnotetext{
${ }^{28}$ See Schneider (1997, 1998a), Johnson, Kaufmann and Zoido-Lobatón (1998a), and Williams and Windebank (1995).

${ }^{29)}$ See Thomas (1992, 1999), Feige (1986), and Pozo (1996).

${ }^{30)}$ One (weak) justification for the use of only the tax variable is that this variable has by far the strongest impact on the size of the shadow economy in the studies known to the authors. The only exception is the study by Frey and Weck-Hannemann (1984) where the variable „tax immorality“ has a quantitatively larger and statistically stronger influence than the direct tax share in the model approach. In the study of Pommerehne and Schneider (1985), for the U.S., besides various tax measures, data for regulation, tax immorality, minimum wage rates are available, the tax variable has a dominating influence and contributes roughly 60-70 percent to the size of the shadow economy. See also Zilberfarb (1986).

${ }^{31)}$ In another study by Tanzi (1982, esp. pp. 110-113) he explicitly deals with this criticism. A very careful investigation of the amount of US-\$ used abroad and the US currency used in the shadow economy and to "classical" crime activities has been undertaken by Rogoff (1998), who concludes that large denomination bills are major driving force for the growth of the shadow economy and classical crime activities due to reduced transactions costs.
} 
Thomas $(1986,1992,1999)$ claim that Tanzi's parameter estimates are not very stable. $^{32)}$

(v) Another weak point of this procedure, in most studies, is the assumption of the same velocity of money in both types of economies. As Hill and Kabir (1996) for Canada and Klovland (1984) for the Scandinavian countries argue, there is already considerable uncertainty about the velocity of money in the official economy; the velocity of money in the hidden sector is even more difficult to estimate. Without knowledge about the velocity of currency in the shadow economy, one has to accept the assumption of an ,equal“" money velocity in both sectors.

(vi) Finally, the assumption of no shadow economy in a base year is open to criticism. Relaxing this assumption would again imply an upward adjustment of the figures attained in the bulk of the studies already undertaken.

\subsubsection{The Physical Input (Electricity) Method}

\section{(1) The Kaufmann - Kaliberda Method $^{33)}$}

To measure overall (official and unofficial) economic activity in an economy, Kaufmann and Kaliberda (1996) assume that electric-power consumption is regarded as the single best physical indicator of overall economic activity. Overall (official and unofficial) economic activity and electricity consumption have been empirically observed throughout the world to move in lockstep with an electricity/GDP elasticity usually close to one. By having a proxy measurement for the overall economy and subtracting it from estimates of official GDP, Kaufmann and Kaliberda derive an estimate of unofficial GDP. This means, that Kaufmann and Kaliberda suggest, that the growth of total electricity consumption is an indicator for representing a growth of official and unofficial GDP. According to this approach, the difference between the gross rate of registered (official) GDP and the cross rate of total electricity consumption can be attributed to the growth of the shadow economy. This method is very simple and appealing, however, it can also be criticized on various grounds:

\footnotetext{
${ }^{32)}$ However in studies for European countries Kirchgaessner $(1983,1984)$ and Schneider (1986) reach the conclusion that the estimation results for Germany, Denmark, Norway and Sweden are quite robust when using the currency demand method. Hill and Kabir (1996) find for Canada that the rise of the shadow economy varies with respect to the tax variable used; they conclude ,when the theoretically best tax rates are selected and a range of plausible velocity values is used, this method estimates underground economic growth between 1964 and 1995 at between 3 and 11 percent of GDP.“ (Hill and Kabir [1996, p. 1553]).

${ }^{33)}$ This method was used earlier by Lizzeri (1979), Del Boca and Forte (1982), and then was used much later by Portes (1996), Kaufmann and Kaliberda (1996), Johnson, Kaufmann and Shleifer (1997). For a
} 
(i) Not all shadow economy activities require a considerable amount of electricity (e.g. personal services), and other energy sources can be used (gas, oil, coal, etc.), so that only a part of the shadow economy will be captured.

(ii) Over time, there has been considerable technical progress. Both the production and use of electricity are more efficient than in the past, and that will apply in both official and unofficial uses.

(iii) There may be considerable differences or changes in the elasticity of electricity/GDP across countries and over time. ${ }^{34)}$

\section{(2) The Lackó Method}

Lackó (1996, 1998, 1999) assumes that a certain part of the shadow economy is associated with the household consumption of electricity. It comprises, among others, the so-called household production, do-it-yourself activities, and other non registered production and services. Lackó assumes that in countries where the section of the shadow economy associated with the household electricity consumption is high, the rest of the hidden economy, that is the part Lackó cannot measure, will also be high. Lackó (1996, pp.19 ff.) assumes that in each country a part of the household consumption of electricity is used in the shadow economy.

Lackó's approach (1998, p.133) can be described by the following two equations:

$\ln \mathrm{E}_{\mathrm{i}}=\alpha_{1} \ln \mathrm{C}_{\mathrm{i}}+\alpha_{2} \ln \mathrm{PR}_{\mathrm{i}}+\alpha_{3} \mathrm{G}_{\mathrm{i}}+\alpha_{4} \mathrm{Q}_{\mathrm{i}}+\alpha_{5} \mathrm{H}_{\mathrm{i}}+\mathrm{u}_{\mathrm{i}}$

with $\quad \alpha_{1}>0, \alpha_{2}<0, \alpha_{3}>0, \alpha_{4}<0, \alpha_{5}>0$

$\mathrm{H}_{\mathrm{i}} \quad=\beta_{1} \mathrm{~T}_{\mathrm{i}}+\beta_{2}\left(\mathrm{~S}_{\mathrm{i}}-\mathrm{T}_{\mathrm{i}}\right)+\beta_{3} \mathrm{D}_{\mathrm{i}}$

with $\beta_{1}>0, \beta_{2}<0, \beta_{3}>0$

where

i: the number assigned to the country,

$\mathrm{E}_{\mathrm{i}}$ : per capita household electricity consumption in country $\mathrm{i}$ in Mtoe,

$\mathrm{C}_{\mathrm{i}}$ : per capita real consumption of households without the consumption of electricity in country $i$ in US dollars (at purchasing power parity),

$\mathrm{PR}_{\mathrm{i}}$ : the real price of consumption of $1 \mathrm{kWh}$ of residential electricity in US dollars (at purchasing power parity),

critique see Lackó (1996, 1997a, 1997b, 1998).

${ }^{34)}$ Johnson, Kaufmann and Shleifer (1997) make an attempt to adjust for changes in the elasticity of 
$\mathrm{G}_{\mathrm{i}}$ : the relative frequency of months with the need of heating in houses in country $\mathrm{i}$,

$\mathrm{Q}_{\mathrm{i}}$ : the ratio of energy sources other than electricity energy to all energy sources in household energy consumption,

$\mathrm{H}_{\mathrm{i}}$ : the per capita output of the hidden economy,

$\mathrm{T}_{\mathrm{i}}$ : the ratio of the sum of paid personal income, corporate profit and taxes on goods and services to GDP,

$\mathrm{S}_{\mathrm{i}}$ : the ratio of public social welfare expenditures to GDP, and

$\mathrm{D}_{\mathrm{i}}$ : the sum on number of dependants over 14 years and of inactive earners, both per 100 active earners.

In a cross country study, she econometrically estimates equation (1) substituting $\mathrm{H}_{\mathrm{i}}$ by equation (2). The econometric estimation results can then be used to establish an ordering of the countries with respect to electricity use in their shadow economies. For the calculation of the actual size (value added) of the shadow economy, Lackó should know how much GDP is produced by one unit of electricity in the shadow economy of each country. Since these data are not known, she takes the result of one of the known shadow economy estimations, that were carried out for a market economy with another approach for the early 1990s, and she applies this proportion to the other countries. Lackó used the shadow economy of the United States as such a base (the shadow economy value of $10.5 \%$ of GDP taken from Morris(1993)), and then she calculates the size of the shadow economy for other countries. Lackó's method is also open to criticism:

(i) Not all shadow economy activities require a considerable amount of electricity and other energy sources can be used.

(ii) Shadow economy activities do not take place only in the household sector.

(iii) It is doubtful whether the ratio of social welfare expenditures can be used as the explanatory factor for the shadow economy, especially in transition and developing countries.

It is questionable which is the most reliable base value of the shadow economy in order to calculate the size of the shadow economy for all other countries, especially, for the transition and developing countries.

electricity/GDP. 


\subsection{The model approach ${ }^{35}$}

All methods described so far that are designed to estimate the size and development of the shadow economy consider just one indicator that "must" capture all effects of the shadow economy. However, it is obvious that its effects show up simultaneously in the production, labor, and money markets. An even more important critique is that the causes which determine the size of the hidden economy are taken into account only in some of the monetary approach studies which usually consider one cause, the burden of taxation. The model approach explicitly considers multiple causes leading to the existence and growth as well as the multiple effects of the shadow economy over time. The empirical method used is quite different from those used so far. It is based on the statistical theory of unobserved variables, which considers multiple causes and multiple indicators of the phenomenon to be measured. For the estimation, a factor-analytic approach is used to measure the hidden economy as an unobserved variable over time. The unknown coefficients are estimated in a set of structural equations within which the "unobserved" variable cannot be measured directly. The DYMIMIC (dynamic multiple-indicators multiple-causes) model consists in general of two parts, the measurement model links the unobserved variables to observed indicators. The structural equations model specifies causal relationships among the unobserved variables. In this case, there is one unobserved variable, the size of the shadow economy. It is assumed to be influenced by a set of indicators for the shadow economy's size, thus capturing the structural dependence of the shadow economy on variables that may be useful in predicting its movement and size in the future. The interaction over time between the causes $Z_{i t}(i=1,2, \ldots, k)$ the size of the shadow economy $X_{t}$, and the indicators $Y_{j t}(j=1,2, \ldots, p)$ is shown in Figure 1.

\footnotetext{
${ }^{35)}$ This part is a summarized version from a longer study by Aigner, Schneider, and Ghosh (1988, p. 303), applying this approach for the United States over time. The pioneers of this approach are Weck (1983), Frey and Weck-Hannemann (1984), who applied this approach to cross-section data from the 24 OECD countries for various years. Before turning to this approach they developed the concept of „soft modeling“ (Frey, Weck, and Pommerehne (1982), Frey and Weck (1983a and 1983b)), an approach which has been used to provide a ranking of the relative size of the shadow economy in different countries.
} 
Figure 1: Development of the shadow economy over time.

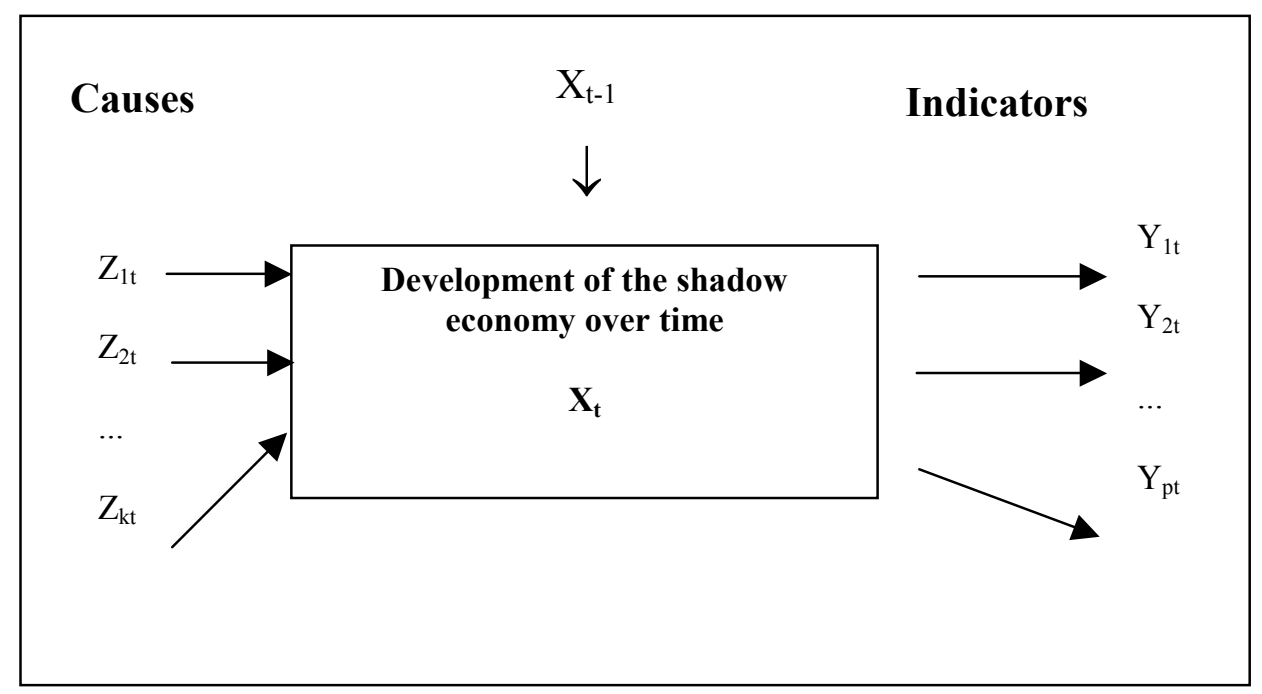

There is a large body of literature ${ }^{36)}$ on the possible causes and indicators of the shadow economy, in which the following three types of causes are distinguished:

\section{Causes}

(i) The burden of direct and indirect taxation, both actual and perceived: a rising burden of taxation provides a strong incentive to work in the shadow economy.

(ii) The burden of regulation as proxy for all other state activities: it is assumed that increases in the burden of regulation give a strong incentive to enter the shadow economy.

(iii) The „tax morality“ (citizens' attitudes toward the state), which describes the readiness of individuals (at least partly) to leave their official occupations and enter the shadow economy: it is assumed that a declining tax morality tends to increase the size of the shadow economy. ${ }^{37}$

\footnotetext{
${ }^{36)}$ Thomas (1992); Schneider (1994a, 1997); Pozo (1996); Johnson, Kaufmann and Zoido-Lobatón (1998a, 1998b); and Giles (1999a, 1999b).

37) When applying this approach for European countries, Frey and Weck-Hannemann (1984) had the difficulty in obtaining reliable data for the cause series, besides the ones of direct and indirect tax burden. Hence, their study was criticized by Helberger and Knepel (1988), who argue that the results were unstable with respect to changing variables in the model and over the years.
} 


\section{Indicators}

A change in the size of the shadow economy may be reflected in the following indicators:

(i) Development of monetary indicators: if activities in the shadow economy rise, additional monetary transactions are required.

(ii) Development of the labor market: increasing participation of workers in the hidden sector results in a decrease in participation in the official economy. Similarly, increased activities in the hidden sector may be expected to be reflected in shorter working hours in the official economy.

(iii) Development of the production market: an increase in the shadow economy means that inputs (especially labor) move out of the official economy (at least partly); this displacement might have a depressing effect on the official growth rate of the economy.

The latest use of the model approach has been undertaken by Giles (1999a, 1999b) and by Giles, Linsey and Gupsa (1999). They basically estimates a comprehensive (dynamic) DYMIMIC (multiple indicators and multiple causes) model to get a time serious index of the hidden/measured output of New Zealand or Canada, and then estimate a separate "cash-demand model" to obtain a benchmark for converting this index into percentage units. Unlike earlier empirical studies of the hidden economy, they paid proper attention to the non-stationary, and possible co-integration of time serious data in both models. Again this DYMIMIC model treats hidden output as a latent variable, and uses several (measurable) causal variables and indicator variables. The former include measures of the average and marginal tax rates, inflation, real income and the degree of regulation in the economy. The latter include changes in the (male) labor force participation rate and in the cash/money supply ratio. In their cash-demand equation they allow for different velocities of currency circulation in the hidden and recorded economies. Their cash-demand equation is not used as an input to determine the variation in the hidden economy over time - it is used only to obtain the long-run average value of hidden/measured output, so that the index for this ratio predicted by the DYMIMIC model can be used to calculate a level and the percentage units of the shadow economy. Giles latest combination of the currency demand and DYMIMIC approach clearly shows that some progress in the estimation technique of the shadow economy has been achieved and a number of critical points have been overcome. 


\section{Summary and Conclusions}

There are many obstacles to be overcome to measure the size of the shadow economy (either in value added and/or in the labor force units) and to analyze its consequences on the official economy, although some progress has been made. In this paper has been shown that though it is difficult to estimate the size of the shadow economy, it is not impossible. It has been demonstrated that with various methods, e.g. the currency demand and the model approach, some insights can be provided into the size and development of the shadow economy (labor force) of 22 Transition and 21 OECD countries. The general impression from the results of these estimations is that for all countries investigated the shadow economy (labor force) has reached a remarkably large size. Over 2000/2001 on average the shadow economy in terms of value added (labor force) was 38\% (30.2\%) in the 22 Transition and $16.7 \%$ (15.3\%)of official GDP in the 21 OECD countries.

To summarize - or what do we really know? There is a common finding that the size of the shadow economies for the 22 Transition and 21 OECD countries has been growing over the decade of the 90s. A similar finding can be made for the ,shadow labor market“ which is attracting a growing attention due to high unemployment in European OECD countries. Furthermore, the results of this study show that an increasing burden of taxation and social security payments, combined with rising state regulatory activities, are the major driving forces for the size and growth of the shadow economy. Finally, to conclude: Shadow economies are a complex phenomenon, present to an important extent even in the industrialized and developed economies. People engage in shadow economic activity for a variety of reasons, among most important, of which we can count are government actions, most notable taxation and regulation. With these two insights, goes a third, no less important one: a government aiming to decrease shadow economic activity has to first and foremost analyze the complex and frequently contradictory relationships among consequences of its own policy decisions. 


\section{References}

Aigner, Dennis; Schneider, Friedrich and Damayanti Ghosh (1988): Me and my shadow: estimating the size of the US hidden economy from time series data, in W. A. Barnett; E. R. Berndt and H. White (eds.): Dynamic econometric modeling, Cambridge (Mass.): Cambridge University Press, pp. 224-243.

Bartlett, Bruce (1998): Corruption, the underground economy, and taxation. Washington D.C.: National Center for Policy Analysis, unpublished manuscript.

Bhattacharyya, D.K. (1999): On the Economic Rationale of Estimating the Hidden Economy, The Economic Journal 109/456, pp. 348-359.

Blades, Derek (1982): "The Hidden Economy and the National Accounts", OECD (Occasional Studies), Paris, pp. 28-44.

Boeschoten, Werner C. and Marcel M.G. Fase (1984): The volume of payments and the informal economy in the Netherlands 1965-1982, M. Nijhoff, Dordrecht.

Brehm, J.W. (1966): A theory of psychological reactance. New York (Academic Press).

Brehm, J.W. (1972): Responses to loss of freedom. A theory of psychological reactance. Morristown (General Learning Press).

Cagan, Phillip (1958): “The Demand for Currency Relative to the Total Money Supply," Journal of Political Economy, 66:3, pp. 302-328.

Cappiello, M.A: (1986): "Proposita di bibliografia ragionata sull'economia sommersa nell'industria (Italia 1970-82)", pp. 307-345, in: Bagnasco, A. (ed.): L'altra metà dell'economia. La ricerca internazionale sull'economia informale, Liguori, Naples.

Cebula, Richard J. (1997): “An Empirical Analysis of the Impact of Government Tax and Auditing Policies on the Size of the Underground Economy: The Case of the United States, 1993-94:" American Journal of Economics and Sociology, 56:2, pp.173-185.

Chickering, Lawrence A. and Muhamed Salahdine (eds.) (1991): The silent revolution-The informal sector in five Asian and near Eastern countries, San Francisco: An International Center for Economic Growth Publication (ICS Press).

Clotefelter, Charles T. (1983): Tax evasion and tax rates: An analysis of individual return, Review of Economic Statistics, 65/3, pp. 363-373.

Contini, Bruno (1981): Labor market segmentation and the development of the parallel economy - the Italian experience, Oxford Economic Papers, 33/4, pp. 401-12.

Dallago, Bruno (1990): The irregular economy: The "underground economy" and the "black labor market”, Dartmouth (U.K.), Publishing Company.

De Grazia, Raffaele (1983). Le traveil clandestin: Situation dans les pays industrialisés à économic de marché, Genf.

Del Boca, Daniela. (1981): Parallel economy and allocation of time, Micros (Quarterly Journal of Microeconomics), 4/2, pp. 13-18.

Del Boca, Daniela and Francesco Forte (1982): Recent empirical surveys and theoretical interpretations of the parallel economy in Italy; Tanzi, Vito (1982) (ed.): The underground economy in the United States and abroad, Lexington (Mass.), Lexington, pp. 160-178. 
Feige, Edgar L. (1986): A re-examination of the "Underground Economy" in the United States. IMF Staff Papers, 33/ 4, pp. 768-781.

Feige, Edgar L. (1989) (ed.): The underground economies. Tax evasion and information distortion. Cambridge, New York, Melbourne, Cambridge University Press.

Feige, Edgar L. (1994): The underground economy and the currency enigma, Supplement to Public Finance/ Finances Publiques, 49, pp. 119-136.

Feige, Edgar L. (1996): Overseas holdings of U.S. currency and the underground economy, in: Pozo, Susan (ed.): Exploring the Underground Economy. Kalamazoo, Michigan, pp. 5-62.

Franz, A. (1983): Wie groß ist die "schwarze" Wirtschaft?, Mitteilungsblatt der Österreichischen Statistischen Gesellschaft, 49/1, pp. 1-6.

Frey, Bruno S. and Hannelore Weck (1983a): "Bureaucracy and the Shadow Economy: A MacroApproach", in Horst Hanusch (ed.): Anatomy of Government Deficiencies. Berlin: Springer, pp. 89-109.

Frey, Bruno S. and Hannelore Weck (1983b): "Estimating the Shadow Economy: A 'Naive' Approach," Oxford Economic Papers, 35, pp. 23-44.

Frey, Bruno S. and Hannelore Weck-Hannemann (1984): The hidden economy as an "unobserved" variable, European Economic Review, 26/1, pp. 33-53.

Frey, Bruno S. and Werner Pommerehne (1984): The hidden economy: State and prospect for measurement, Review of Income and Wealth, 30/1, pp. 1-23.

Frey, Bruno S., Weck Hannelore and Werner W. Pommerehne (1982): Has the shadow economy grown in Germany? An exploratory study, Weltwirtschaftliches Archiv, 118/4, pp. 499-524.

Frey, L. (1972): Il lavoro a domicilio in Lombardia, Giunta Regionale Lombarda, Assessorato al Lavoro, Milan.

Frey, L. (1975): Il potenziale di lavoro in Italia, Documenti ISVET, no. 50.

Frey, L. (1978): “Il lavoro nero nel 1977 in Italia”, Tendenze della occupazione, no. 6.

Frey, L. (1980): "Introduzione all'analisi economica del lavoro minorile", Economia del Lavoro, no. $1-2$, pp. 5-16.

Friedman, E., Johnson, S., Kaufmann, D. and Zoido-Labton, P. (1999): Dodging the grabbing hand: The determinants of unofficial activity in 69 countries, Discussion paper, Washington D.C: World Bank.

Garcia, Gillian (1978): “The Currency Ratio and the Subterranean Economy," Financial Analysts Journal, 69:1, pp. 64-66.

Giles, David, E.A. (1999a): Measuring the hidden economy: Implications for econometric modelling, The Economic Journal, 109/456, pp.370-380.

Giles, David, E.A. (1999b): Modelling the hidden economy in the tax-gap in New Zealand, Working paper, Department of Economics, University of Victoria, Canada.

Giles, David, E.A., Tedds, Linsey, M. and Werkneh, Gugsa (1999): The Canadian underground and measured economies, Working paper, Department of Economics, University of Victoria, Canada. 
Gretschmann, Klaus (1984). Wohlfahrtseffekte schattenwirtschaftlicher Aktivitäten? In Klaus Gretschmann; Rolf G. Heinze; Bernd Mettelsiefen (Ed.), Schattenwirtschaft. Wirtschaftsund sozialwissenschaftliche Aspekte, internationale Erfahrungen, . Göttingen: Vandenhoeck u. Rubrecht.

Gutmann, Pierre M. (1977): “The Subterranean Economy,” Financial Analysts Journal, 34:1, pp. 24-27.

Helberger, Claus and Hans Knepel (1988): "How big is the shadow economy? A re-analysis of the unobserved-variable approach of B. S. Frey and H. Weck-Hannemann", European Economic Journal, 32, pp. 965-76.

Hill, Roderick and Muhammed Kabir (1996): Tax rates, the tax mix, and the growth of the underground economy in Canada: What can we infer? Canadian Tax Journal/ Revue Fiscale Canadienne, 44/ 6, pp. 1552-1583.

IRS (1979): Estimates of income unreported on individual tax reforms, Washington D.C.: Internal revenue service, U.S. Department of the Treasury.

IRS (1983): Income tax compliance research: Estimates for 1973-81, Washington D.C.: Internal revenue service, U.S. Department of the Treasury.

Isachsen, Arne J. and Steinar Strom (1985): The size and growth of the hidden economy in Norway, Review of Income and Wealth, 31/1, pp. 21-38.

Isachsen, Arne J.; Klovland, Jan and Steinar Strom (1982): The hidden economy in Norway, in: Tanzi Vito (ed.): The underground economy in the United States and Abroad, Heath, Lexington, pp. 209-231.

Johnson, Simon; Kaufmann, Daniel; and Andrei Shleifer (1997): The unofficial economy in transition, Brookings Papers on Economic Activity, Fall, Washington D.C.

Johnson, Simon; Kaufmann, Daniel and Pablo Zoido-Lobatón (1998a): Regulatory discretion and the unofficial economy. The American Economic Review, 88/ 2, pp. 387-392.

Johnson, Simon; Kaufmann, Daniel and Pablo Zoido-Lobatón (1998b): Corruption, public finances and the unofficial economy. Washington, D.C.: The World Bank, discussion paper.

Kaufmann, Daniel and Kaliberda, Aleksander (1996), Integrating the unofficial economy into the dynamics of post socialist economies: A framework of analyses and evidence, Washington, D.C., The Worldbank, Policy research working paper 1691.

Kirchgaessner, Gebhard (1983): Size and development of the West German shadow economy, 1955-1980, Zeitschrift für die gesamte Staatswissenschaft, 139/2, pp. 197-214.

Kirchgaessner, Gebhard (1984): Verfahren zur Erfassung des in der Schattenwirtschaft erarbeiteten Sozialprodukts, Allgemeines Statistisches Archiv, 68/4, pp. 378-405.

Klovland, Jan (1984): "Tax Evasion and the Demand for Currency in Norway and Sweden: Is there a Hidden Relationship?" Scandinavian Journal of Economics, 86:4, pp. 423-39.

Lackó Mária (1996): Hidden economy in East-European countries in international comparison, Laxenburg: International Institute for Applied Systems Analysis (IIASA), working paper.

Lackó Mária (1997a): The hidden economies of Visegrád countries in international comparison: A household electricity approach, Hungary: Institute of Economics, working paper. 
Lackó Mária (1997b): Do power consumption data tell the story? (Electricity Intensity and the hidden economy in Post-Socialist countries), Laxenburg: International Institute for Applied Systems Analysis (IIASA), working paper.

Lackó Mária (1998): The hidden economies of Visegrad countries in international comparison: A household electricity approach, In: Halpern, L. and Wyplosz, Ch. (eds.), Hungary: Two wards a market economy, Cambridge (Mass.): Cambridge University Press, p.128-152.

Langfeldt, Enno (1984): The unobserved economy in the Federal Republic of Germany, in: Feige, Edgar L. (ed.): The unobserved economy, Cambridge University Press., pp. 236-260.

Lemieux, Thomas; Fortin, Bernard; and Pierre Fréchette (1994):The effect of taxes on labor supply in the underground economy. The American Economic Review, 84/No. 1, pp. 231254.

Lippert, Owen and Michael Walker (eds.) (1997): The underground economy: Global evidences of its size and impact, Vancouver, B.C.: The Frazer Institute.

Lizzeri, C. (1979): Mezzogiorno in controluce. Enel, Naples.

Loayza, Norman V. (1996): The economics of the informal sector: a simple model and some empirical evidence from Latin America. Carnegie-Rochester Conference Series on Public Policy 45, pp. 129-162.

Lubell, Herald (1991): The informal sector in the 1980's and 1990's, Paris: OECD.

MacAfee, Kerrick (1980): A Glimpse of the hidden economy in the national accounts, Economic Trends, 136, pp. 81-87.

Mauleon, Ignacio (1998): Quantitative Estimation of the Spanish Underground Economy, Discussion paper, Department of Economics and History, University of Salamanka, Salamanka, Spain.

Mogensen, Gunnar V.; Kvist, Hans K.; Körmendi, Eszter and Soren Pedersen (1995): The shadow economy in Denmark 1994: Measurement and results, Study no. 3, Copenhagen: The Rockwool Foundation Research Unit.

Mummert, Annette and Friedrich Schneider (2001): The German Shadow Economy: parted in a United Germany?, Linz, University of Linz, Department of Economics, Discussion paper.

O'Higgins, Michael (1989): Assessing the underground economy in the United Kingdom, in: Feige, E.L. (ed.): The underground economies: tax evasion and information distortion, Cambridge: Cambridge University Press, pp. 175-195.

O'Neill, David M. (1983): Growth of the underground economy 1950-81: Some evidence from the current population survey, Study for the Joint Economic Committee, U.S. Congress, Joint Committee Print 98-122, U.S. Gov. Printing Office, Washington.

Park, T. (1979): Reconciliation between personal income and taxable income, pp. 1947-77, mimeo, Washington D.C.: Bureau of Economic Analysis.

Pelzmann, Linde (1988): Wirtschaftspsychologie. Arbeitslosenforschung, Schattenwirtschaft, Steuerpsychologie. Wien, New York (Springer).

Petersen, Hans-Georg (1982): Size of the public sector, economic growth and the informal economy: Development trends in the Federal Republic of Germany, Review of Income and Wealth, 28/2, pp. 191-215. 
Pissarides, C. and Weber, G. (1988): An expenditure - based estimate of Britain's black economy, CLE working paper no. 104, London.

Portes, Alejandro (1996): The informal economy, in: Pozo, Susan (ed.): Exploring the underground economy. Kalamazoo, Michigan, pp. 147-165.

Pozo, Susan (ed.) (1996): Exploring the underground economy: Studies of illegal and unreported activity, Michigan: W.E. Upjohn, Institute for Employment Research.

Schneider, Friedrich (1986): Estimating the size of the Danish shadow economy using the currency demand approach: An attempt, The Scandinavian Journal of Economics, 88/4, pp. 643-668.

Schneider, Friedrich (1994a): Measuring the size and development of the shadow economy. Can the causes be found and the obstacles be overcome? in: Brandstaetter, Hermann, and Güth, Werner (eds.): Essays on Economic Psychology, Berlin, Heidelberg, Springer Publishing Company, pp. 193-212.

Schneider, Friedrich (1994b): Can the shadow economy be reduced through major tax reforms? An empirical investigation for Austria, Supplement to Public Financel Finances Publiques, 49, pp. 137-152.

Schneider, Friedrich (1997): The shadow economies of Western Europe, Journal of the Institute of Economic Affairs, 17/3, pp. 42-48.

Schneider, Friedrich (1998a): Further empirical results of the size of the shadow economy of 17 OECD-countries over time, Paper presented at the 54. Congress of the IIPF Cordowa, Argentina and discussion paper, Department of Economics, University of Linz, Linz, Austria.

Schneider, Friedrich (1998b): Stellt das Anwachsen der Schwarzarbeit eine wirtschaftspolitische Herausforderung dar? Einige Gedanken aus volkswirtschaftlicher Sicht. Linz, Mitteilungen des Instituts für angewandte Wirtschaftsforschung (IAW), I/98, S. 4-13.

Schneider, Friedrich (2000), The Increase of the Size of the Shadow Economy of 18 OECDCountries: Some Preliminary Explanations, Paper presented at the Annual Public Choice Meeting, March 10-12, 2000, Charleston, S.C.

Schneider, Friedrich (2001). Arbeit im Schatten: Einige theoretische und empirische Überlegungen über die Schattenwirtschaft, Perspektiven der Wirtschaftspolitik, Vol. 2, Heft 4, Oktober 2001.

Schneider, Friedrich and Dominik Enste (2000): Shadow Economies: Size, Causes, and Consequences, The Journal of Economic Literature, 38/1, pp. 77-114.

Simon, C.B. and A.G. Witte (1982): Beating the system: The underground economy, Boston, (Mas.): Urban House.

Smith, J.D (1985): Market motives in the informal economy, in: Gaertner, W. and Wenig, A. (eds.): The economics of the shadow economy, Heidelberg: Springer Publishing Company, pp. 161-177.

Spiro, Peter S. (1993): "Evidence of a Post-GST Increase in the Underground Economy;" Canadian Tax Journal/ Revue Fiscale Canadienne, , 41:2, pp. 247-258.

Tanzi, Vito (1980): "The Underground Economy in the United States: Estimates and Implications," Banca Nazionale del Lavoro, 135:4, pp. 427-453. 
Tanzi, Vito (1982) (ed.): The underground economy in the United States and abroad, Lexington (Mass.), Lexington.

Tanzi, Vito (1982): A second (and more skeptical) look at the underground economy in the United States; in: Tanzi, Vito (1982) (ed.): The underground economy in the United States and abroad, Lexington (Mass.), Lexington, pp. 38-56.

Tanzi, Vito (1983): "The Underground Economy in the United States: Annual Estimates, 19301980, “IMF-Staff Papers, 30:2, pp. 283-305.

Tanzi, Vito (1986): The underground economy in the United States, Reply to comments by Feige, Thomas, and Zilberfarb. IMF - Staff Papers, 33/ 4, pp. 799-811.

Tanzi, Vito (1999): Uses and Abuses of Estimates of the Underground Economy, The Economic Journal 109/456, pp.338-340.

Thomas, Jim J. (1986): The underground economy in the United States: A comment on Tanzi, IMF-Staff Papers, Vol. 33, No. 4, pp. 782-789.

Thomas, Jim J. (1992): Informal economic activity, LSE, Handbooks in Economics, London: Harvester Wheatsheaf.

Thomas, Jim J. (1999): Quantifying the Black Economy: 'Measurement without Theory' Yet Again?, The Economic Journal 109/456, pp. 381-389.

Weck, Hannelore (1983): Schattenwirtschaft: Eine Möglichkeit zur Einschränkung der öffentlichen Verwaltung? Eine ökonomische Analyze, Bern-Frankfurt.

Williams, Colin C. and Jan Windebank (1995): "Black market work in the European Community: Peripheral work for peripheral localities?", International Journal of Urban and Regional Research, 19/1, pp. 23-39.

Witte, A.D. (1987): The nature and extend of unreported activity: A survey concentrating on a recent US-research, in: Alessandrini, S. and Dallago, B. (eds.): The unofficial economy: Consequences and perspectives in different economic systems, Gower: Aldershot.

Zilberfarb, Ben-Zion (1986): Estimates of the underground economy in the United States, 193080. IMF-Staff Papers, 33/ 4, pp. 790-798. 


\section{IZA Discussion Papers}

\begin{tabular}{|c|c|c|c|c|}
\hline No. & Author(s) & Title & Area & Date \\
\hline 497 & D. Gatti & $\begin{array}{l}\text { European Integration and Employment: } \\
\text { A New Role for Active Fiscal Policies? }\end{array}$ & 2 & $05 / 02$ \\
\hline 498 & $\begin{array}{l}\text { P. Frijters } \\
\text { J. P. Haisken-DeNew } \\
\text { M. A. Shields }\end{array}$ & $\begin{array}{l}\text { Individual Rationality and Learning: Welfare } \\
\text { Expectations in East Germany Post- } \\
\text { Reunification }\end{array}$ & 6 & $05 / 02$ \\
\hline 499 & $\begin{array}{l}\text { G. A. Pfann } \\
\text { H. van Kranenburg }\end{array}$ & $\begin{array}{l}\text { Tax Policy, Location Choices, and Market } \\
\text { Structure }\end{array}$ & 6 & $05 / 02$ \\
\hline 500 & D. A. Jaeger & $\begin{array}{l}\text { Estimating the Returns to Education Using the } \\
\text { Newest Current Population Survey Education } \\
\text { Questions }\end{array}$ & 6 & 05/02 \\
\hline 501 & $\begin{array}{l}\text { C. Dustmann } \\
\text { N. Rajah } \\
\text { A. van Soest }\end{array}$ & Class Size, Education, and Wages & 5 & $05 / 02$ \\
\hline 502 & $\begin{array}{l}\text { B. R. Chiswick } \\
\text { Y. L. Lee } \\
\text { P. W. Miller }\end{array}$ & $\begin{array}{l}\text { Immigrants' Language Skills: The Australian } \\
\text { Experience in a Longitudinal Survey }\end{array}$ & 1 & $05 / 02$ \\
\hline 503 & $\begin{array}{l}\text { R. Winter-Ebmer } \\
\text { A. Wirz }\end{array}$ & $\begin{array}{l}\text { Public Funding and Enrolment into Higher } \\
\text { Education in Europe }\end{array}$ & 3 & $05 / 02$ \\
\hline 504 & $\begin{array}{l}\text { L. Cappellari } \\
\text { S. P. Jenkins }\end{array}$ & Modelling Low Income Transitions & 4 & 05/02 \\
\hline 505 & T. K. Bauer & Migration, Sozialstaat und Zuwanderungspolitik & 1 & $05 / 02$ \\
\hline 506 & $\begin{array}{l}\text { P. Díaz-Vázquez } \\
\text { D. Snower }\end{array}$ & Can Insider Power Affect Employment? & 3 & $05 / 02$ \\
\hline 507 & $\begin{array}{l}\text { E. Fehr } \\
\text { A. Falk }\end{array}$ & Psychological Foundations of Incentives & 5 & 05/02 \\
\hline 508 & $\begin{array}{l}\text { C. Belzil } \\
\text { J. Hansen }\end{array}$ & Unobserved Ability and the Return to Schooling & 6 & 05/02 \\
\hline 509 & A. Kunze & $\begin{array}{l}\text { The Timing of Careers and Human Capital } \\
\text { Depreciation }\end{array}$ & 1 & 06/02 \\
\hline 510 & E. S. Prasad & Wage Inequality in the United Kingdom, 1975-99 & 2 & 06/02 \\
\hline 511 & $\begin{array}{l}\text { F. Büchel } \\
\text { H. Battu }\end{array}$ & $\begin{array}{l}\text { The Theory of Differential Overqualification: } \\
\text { Does it Work? }\end{array}$ & 1 & $06 / 02$ \\
\hline 512 & $\begin{array}{l}\text { C. Belzil } \\
\text { J. Hansen }\end{array}$ & $\begin{array}{l}\text { A Structural Analysis of the Correlated Random } \\
\text { Coefficient Wage Regression Model }\end{array}$ & 6 & $06 / 02$ \\
\hline 513 & $\begin{array}{l}\text { C. Belzil } \\
\text { J. Hansen }\end{array}$ & $\begin{array}{l}\text { Earnings Dispersion, Risk Aversion and } \\
\text { Education }\end{array}$ & 6 & $06 / 02$ \\
\hline 514 & F. Schneider & $\begin{array}{l}\text { The Size and Development of the Shadow } \\
\text { Economies of } 22 \text { Transition and } 21 \text { OECD } \\
\text { Countries }\end{array}$ & 4 & 06/02 \\
\hline
\end{tabular}

